\title{
41. PLIOCENE-PLEISTOCENE DEPOSITION OF CARBONATE AND ORGANIC CARBON AT SITE 959: PALEOENVIRONMENTAL IMPLICATIONS FOR THE EASTERN EQUATORIAL ATLANTIC OFF THE IVORY COAST/GHANA ${ }^{1}$
}

\author{
Thomas Wagner ${ }^{2}$
}

\begin{abstract}
During Ocean Drilling Program (ODP) Leg 159, four sites (Sites 959-962) were drilled along a depth transect on the Côte d'Ivoire/Ghana Transform Margin. In this study, the Pliocene-Pleistocene history of carbonate and organic carbon accumulation at Hole 959C is reconstructed for the eastern equatorial Atlantic off the Ivory Coast/Ghana based on bulk carbonate, sand fraction, organic carbon, and other organic geochemical records $\left(\delta^{13} \mathrm{C}_{\mathrm{org}}\right.$, marine organic matter percentages derived from organic petrology, hydrogen index, $\mathrm{C} / \mathrm{N})$.

Pliocene-Pleistocene sedimentation off the Ivory Coast/Ghana was strongly affected by low mean sedimentation rates, which are attributed to persistently enhanced bottom-water velocities related to the steep topography of the transform margin. Sand fraction and bulk carbonate records reveal typical glacial/interglacial cycles, preserved, however, with low time resolution. Intermediate carbonate accumulation rates observed throughout the Pliocene-Pleistocene suggest intense winnowing and sediment redistribution superimposed by terrigenous dilution. "Atlantic-type" sand and carbonate cycles, consistent with records from pelagic areas of the eastern equatorial Atlantic, are encountered at Hole 959C prior to about 0.9 Ma. Total organic carbon (TOC) records are frequently inversely correlated to carbonate contents, indicating mainly productivity-driven carbonate dissolution related to changes in paleoproductivity. During Stages 22-24, 20,16, 12, 8, and 4, sand and carbonate records reveal a "Pacific-type" pattern, showing elevated contents during glacials commonly in conjunction with enhanced TOC records. Formation of "Pacific-type" patterns off the Ivory Coast/Ghana is attributed to drastically increased bottom-water intensities along the transform margin in accordance with results reported from the Walvis Ridge area.

Short-term glacial/interglacial changes in paleoproductivity off the Ivory Coast/Ghana are to some extend recognizable during glacials prior to $1.7 \mathrm{Ma}$ and interglacial Stages 21, 19, 13, 9, and 1. Enhanced coastal upwelling during interglacials is attributed to local paleoclimatic and oceanographic conditions off the Ivory Coast/Ghana. Quantitative estimates of marine organic carbon based on organic petrologic and $\delta^{13} \mathrm{C}_{\text {org }}$ records reveal an offset in concentration ranging from $15 \%$ to $60 \%$. Highest variabilities of both records are recorded since $\sim 0.9 \mathrm{Ma}$. Discrepancies between the isotopic and microscopic records are attributed to an admixture of $\mathrm{C} 4$ plant debris approaching the eastern equatorial Atlantic via atmospheric dust. Terrestrial organic material likely originated from the grass-savannah-covered Sahel zone in central Africa. Estimated C4 plant concentrations and accumulation rates range from $10 \%$ to $37 \%$ and from almost zero to $0.006 \mathrm{~g} / \mathrm{cm}^{2} / \mathrm{k}$.y., respectively. The strongest eolian supply to the northern Gulf of Guinea is indicated between 1.9 and 1.68 Ma and during glacial isotopic Stages 22-24, 20, 14 , and 12. The presence of grass-type plant debris is further supported by organic petrologic studies, which reveal well-preserved cell tissues of vascular plants or tube-shaped, elongated terrestrial macerals showing different levels of oxidation.
\end{abstract}

\section{INTRODUCTION}

Four sites (Sites 959-962) were drilled during Ocean Drilling Program (ODP) Leg 159 along a northeast-southwest depth transect on the Côte d'Ivoire/Ghana Transform Margin (see insert map in Fig. 1A; Mascle, Lohmann, Clift, et al., 1996). Site 959, positioned in shallow water ( $2100 \mathrm{~m}$ depth) on a small plateau that extends just north of the top of the margin crest on the southern shoulder of the Deep Ivorian Basin, cored through undisturbed Neogene sediments down into Late Cretaceous strata. One of the paleoceanographic objectives of Leg 159 was to investigate the Pliocene-Pleistocene evolution of carbonate-rich sediments formed under the influence of past intermediate waters. In this study, detailed sedimentological and organic geochemical data obtained from Pliocene-Pleistocene sections of Hole 959C are presented and discussed with regard to their paleoceanographic and paleoclimatic implications for the eastern equatorial Atlantic off the Ivory Coast/Ghana. Special emphasis is placed on the quantity and quality of the organic carbon matter deposited at Hole 959C because detailed studies on the evolution of the organic facies provide important information on the provenance and stage of

${ }^{1}$ Mascle, J., Lohmann, G.P., and Moullade, M. (Eds.), 1998. Proc. ODP, Sci. Results, 159: College Station, TX (Ocean Drilling Program).

${ }^{2}$ Fachbereich 5 - Geowissenschaften, Universität Bremen, Postfach 330440, 28334 Bremen, Federal Republic of Germany. tw@mail.sedpal.uni-bremen.de diagenetic alteration of sedimentary organic matter, its mode of transportation, and the evolution of the depositional environment (Summerhayes, 1986; Jones, 1987; Stein and Littke, 1990). One of the main targets of this study is to provide and compare two independent sets of data that display quantitative proportions of marine and terrestrial sedimentary organic carbon (i.e., the organic carbon isotopic signal $\left[\delta^{13} \mathrm{C}_{\text {org }}\right]$ and the maceral composition [organic petrology]).

It is well documented for the Quaternary subtropical and equatorial Atlantic that orbitally forced changes in the deposition of biogenous carbonate and organic carbon and the displacement of water masses are closely related to the glacial/interglacial evolution of the global atmospheric and oceanic circulation (Verardo and McIntyre, 1994; Bickert and Wefer, 1996; Mix and Morey, 1996, and references therein). Compared to modern or warm interglacial climatic conditions, wind intensities at low latitudes were repetitively enforced during glacial and deglacial periods because of complex feedback mechanisms interacting between the tropical Trade-, Harmattan-, and Monsoon-wind systems and Northern Hemisphere glaciations (Sarnthein et al., 1982; deMenocal et al., 1993).

In the subtropical and equatorial Atlantic, these strengthened wind systems triggered coastal and equatorial upwelling of nutrientrich intermediate waters or lateral cold water advection, which, in turn, caused higher paleoproductivity during glacial periods (Müller et al., 1983; Mix, 1989; Berger and Herguera, 1992). Glacial/interglacial cycles in total organic carbon (TOC) fluxes, reported from sediments along the northwestern (Müller et al., 1983; Stein et al., 
A

W 30 20 10 0 10 20 E

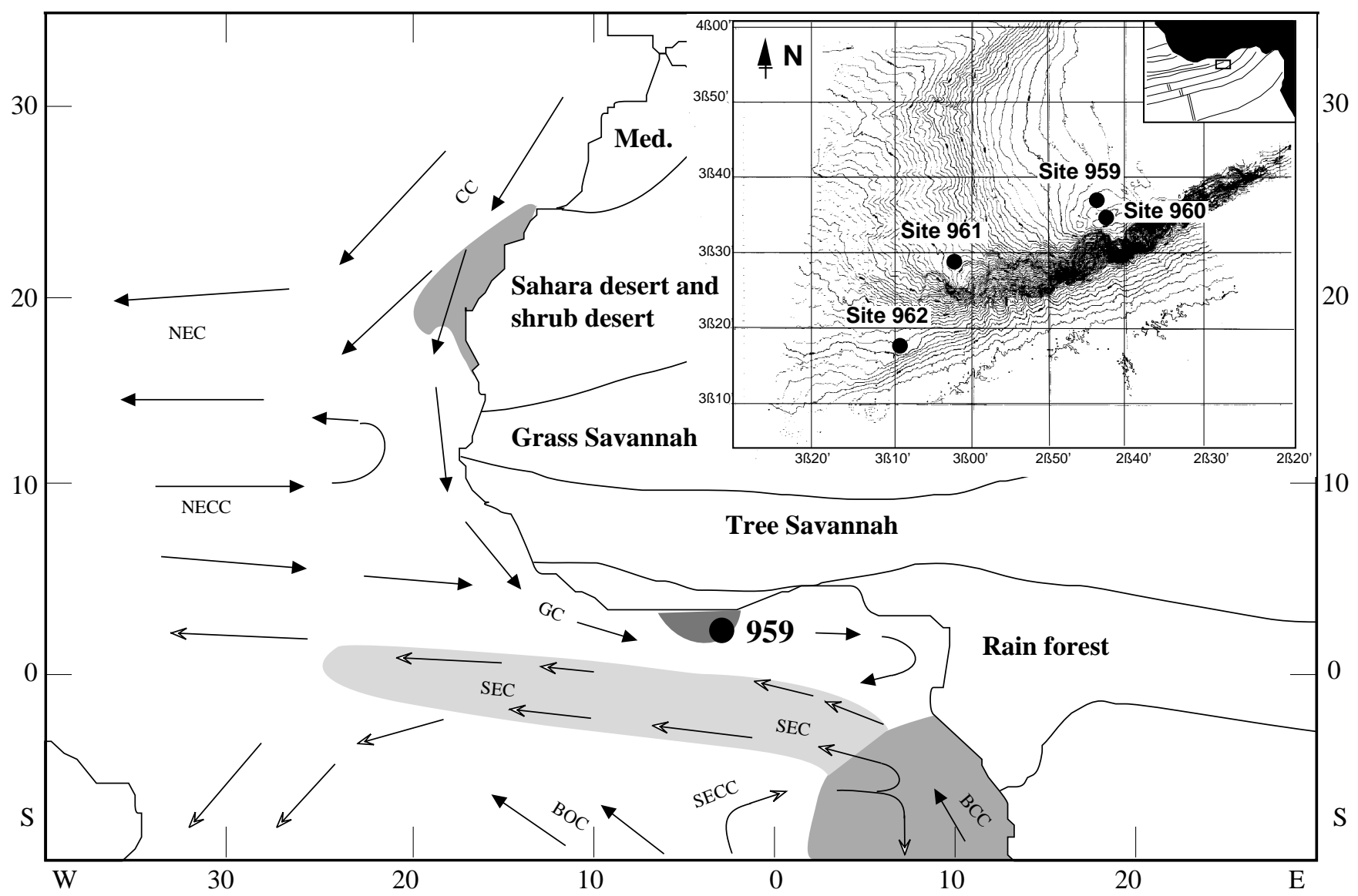

Figure 1. A. Location of Site 959, major African vegetation zones, and general surface currents in the equatorial Atlantic. Insert map shows detailed locations of Sites 959-962 on the Côte-d'Ivoire/Ghana Transform Margin. Solid arrows = cold currents, open arrows = warm currents (Hart and Currie, 1960; van Bennekom and Berger, 1984). Shaded areas = different types of high productivity areas (light gray $=$ equatorial divergence, medium gray = permanent upwelling, dark gray = seasonal upwelling; van Bennekom and Berger, 1984; Voiturez and Herbland, 1982; van Leeuwen, 1989; Verstraete, 1992). Note the position of Site 959 below the seasonally developed upwelling area off the Ivory Coast/Ghana. (Continued next page.)

1989; Abrantes, 1992), eastern equatorial (Müller et al., 1994; Schneider et al., 1996), and southwestern (Calvert and Price, 1983; Hay and Brock, 1992) African margin and in the Equatorial Divergence Zone (Verardo and McIntyre, 1994), are generally interpreted as recording these changes in paleoproductivity.

Under modern climatic conditions, oceanic upwelling occurs in the eastern equatorial Atlantic along the Equatorial Divergence Zone as a result of lateral advection of cold waters from the westward flowing South Equatorial Current (SEC) combined with tradewindinduced divergence (Voiturez and Herbland, 1982; van Leeuwen, 1989; Peterson and Stramma, 1991) and in the high-productivity region of the Angola Basin (van Bennekom and Berger, 1984; Fig. 1A). Wind-induced coastal upwelling is reported all year long from the coastal areas off northwest (Schemainda et al., 1975) and southwest (Hart and Currie, 1960; Lutjeharms and Meeuwis, 1987) Africa and during the boreal summer off the Ivory Coast/Ghana (Voiturez and Herbland, 1982; Verstraete, 1992). The extension of the upwelling region off the Ivory Coast/Ghana clearly covers the position of ODP Site 959 (Fig. 1A) and is measured by heavy carbon isotopic signals of sedimentary organic carbon $\left(\delta^{13} \mathrm{C}_{\mathrm{org}}\right)$, which are interpreted to document a dominance of marine organic carbon in surface sediments along the west African shelf (Westerhausen et al., 1993).

The Trade-, Harmattan-, and Monsoon-wind systems, on the other hand, have a major control over the amount of terrigenous material transported as eolian dust to the Atlantic Ocean. During the boreal summer, dust from the African continent reaches as far west as the Caribbean Sea (Semmelhack, 1943; Schütz, 1980), although most of the atmospheric dust is released to the central and eastern Atlantic (Sarnthein et al., 1982; Ruddiman and Janecek, 1989; Tiedemann et al., 1989; deMenocal et al., 1993; Fig. 1B). In response to the seasonal equatorward movement of the Intertropical Convergence Zone (ITCZ), the dust plume gradually migrates south and approaches its southernmost position during the boreal winter. During this season eolian material is released from the atmosphere over a broad area of the equatorial Atlantic from the Ivory Coast/Ghana in the east to the Brazilian margin in the west. Atmospheric dust obviously influences sedimentation at the location of Site 959 (Fig. 1B). Westerhausen et al. (1993) estimated from n-alkane distribution patterns in surface sediments off the Ivory Coast/Ghana that almost all of the terrestrial organic matter identified in the sediments is derived from eolian supply. Based on mineralogical and palynological evidence, the source areas for eolian dust recovered in equatorial Atlantic deposits are localized in the arid to semiarid zones of central Africa (Pokras and Mix, 1985; Sarnthein et al., 1982; Bonifay and Giresse, 1992).

Continental dust is generally composed of minor amounts of terrestrial organic matter, which, to some extent, represents the vegetation cover of the source area. Remains of terrestrial plants are admixed to lithogenic dust either as highly resistant organic particles or 

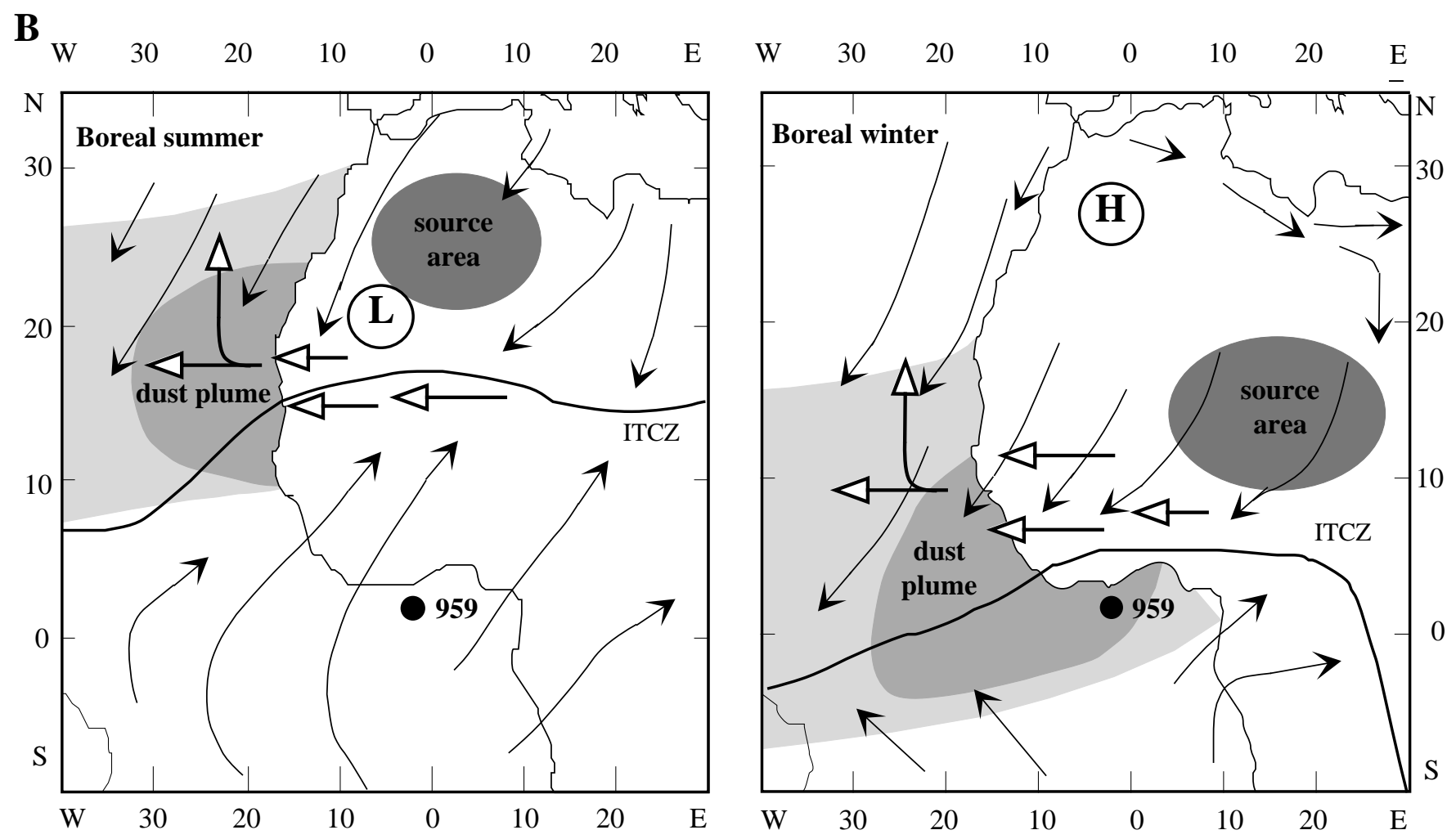

Figure 1 (continued). B. Location of Site 959 and generalized atmospheric circulation patterns during northern summer and winter. Solid arrows $=$ surface winds, open arrows $=$ the mid-level African Easterly Jet (AEJ) and the Saharan Air Layer. Shaded areas = the approximate source areas for dust (dark gray) and corresponding positions of seasonal dust plumes (light gray) (modified after Semmelhack, 1943; Schütz, 1980; Ruddiman et al., 1986; Pokras and Mix, 1985). Note the marginal position of Site 959 below the northern winter dust plume.

as macromolecular compounds of plant biomass depending on the composition and density of the vegetation and its stage of biogeochemical degradation. High abundances of lipids from vascular plants were detected in aerosols collected over the Atlantic (Simoneit, 1977; Chesselet et al., 1981) and the central Pacific Ocean (Chesselet et al., 1981; Gagosian and Peltzer, 1985; Zafiriou et al., 1985; Gagosian et al., 1987; see Prahl and Muehlhausen, 1989, for further discussion). Because of the resistant chemical composition of terrestrial biomass, terrestrial organic matter has an excellent potential to be preserved in marine sediments, either as palynomorphs or as terrestrial biomarkers (Tissot and Welte, 1984). Variable eolian supply of palynomorphs in response to Quaternary climatic cycles is documented in numerous hemipelagic and pelagic records obtained all along the west African margin (Maley, 1982; Turon, 1984; Lézine and Hooghiemstra, 1990; Lézine, 1991; Dupont and Agwu, 1991; Frédoux, 1994) and the central equatorial Atlantic (Pokras and Mix, 1985; Pokras and Ruddiman, 1989; deMenocal et al., 1993; Verardo and Ruddimann, 1996). Climate-related variations in the amount of terrestrial lipids in Cenozoic sediments are reported from the equatorial (Poynter et al., 1989), subtropical (ten Haven et al., 1989), and northeastern Atlantic (Santos et al., 1994), typically revealing elevated concentrations during glacials compared to interglacials.

Contribution of significant amounts of fluviatile material to the location of Hole 959C could be disregarded considering the strongly reduced river discharge from the adjacent coastline and the effective channeling of downslope-moving sediments through the steep "TrouSans-Fond" canyon off Abidjan (Droz et al., 1985; Giresse and Barusseau, 1989). Today, the Comoe river mouth is displaced $30 \mathrm{~km}$ west from the "Trou-Sans-Fond" canyon (Martin, 1974), where it has probably maintained since the Oligocene (Simon and Amakou, 1984).

\section{Stratigraphy and Calculation of Long-Term Fluxes}

Chronostratigraphy of the uppermost 22-m section of Hole 959C is based on stable oxygen and carbon isotope data performed on tests of the epibenthic taxon Cibicides wuellerstorfi at Woods Hole Oceanographic Institution (G.P. Lohmann, pers. comm., 1997) supplemented by the CN14a/b and the CN13b/14a biostratigraphic events (Shin et al., Chap. 39, this volume). Shipboard magnetostratigraphic datings reported for the uppermost $20 \mathrm{~m}$ of Hole 959A were not considered for Hole 959C stratigraphy because of discrepancies between nannofossil and geophysical records. The offset between both sets of datums is striking below the top of Core 159-959C-3H, suggesting either a gap between the two holes or inaccurate determination of magnetostratigraphic ages because of the low intensity of magnetization and eventually drilling-induced magnetization in Hole 959A (see "Magnetostratigraphy" section in the "Site 959" chapter of the Initial Reports volume [Mascle, Lohmann, Clift, et al., 1996]). Correlation of magnetic susceptibility records of all three holes drilled at Site 959 indicates that about $0.4 \mathrm{~m}$ and $4.0 \mathrm{~m}$ of the sediment sequence of Hole $959 \mathrm{C}$ are missing between Cores $159-959 \mathrm{C}-1 \mathrm{H}$ and $2 \mathrm{H}$, and between Cores $159-959 \mathrm{C}-2 \mathrm{H}$ and $3 \mathrm{H}$, respectively. The age model of Hole 959C is based on graphic, computer-aided correlation of the $\delta^{18} \mathrm{O}$ record to the well-dated, high-resolution record of Site 659 (Tiedemann et al., 1994). Definition of oxygen isotopic events and their conversion into absolute ages follows Martinson et al. (1987), with modifications by Berger et al. (1994). Age fixpoints used in this study, corresponding depth levels, sources of datums, mean linear sedimentation rates (LSR) and mean average accumulation rates are listed in Table 1 and are presented in an age/depth plot for Hole 959C in Figure 2. According to the macroscopic shipboard description of lithologies (Mascle, Lohmann, Clift, et al., 1996) no visual evidence 
for slumping or other disturbance of the upper sedimentary column was encountered, indicating a slow but continuous sedimentation on the upper flank of the Côte d'Ivoire-Ghana Transform Margin throughout the Pliocene-Pleistocene. Microstructure analysis revealed a number of millimeter- to centimeter-thick laminae with increased concentrations of foraminifers (Giresse et al., Chap. 43, this volume). Average mean LSR below $1 \mathrm{~cm} / \mathrm{k} . \mathrm{y}$., however, are distinctly lower than the average three to four times higher mean LSR reported from the eastern equatorial Atlantic at water depths between 3500 and 4000 mbsf (Bickert and Wefer, 1996). Determination of mass accumulation rates (AR) of bulk sediment and individual components was performed according to van Andel et al. (1975). Dry bulk density (DBD) is calculated from water contents following Ruddiman and Janecek (1989). Data are reported in Table 2.

\section{SAMPLE PREPARATION AND ANALYTICAL APPROACH}

Water contents were determined from samples taken on board ship. Slices $(2.5 \mathrm{~cm})$ of a quarter core $\left(20-\mathrm{cm}^{3}\right.$ volume $)$ were continuously taken on board and deep frozen immediately after sampling in sealed plastic bags at $-20^{\circ} \mathrm{C}$. Samples were kept deep frozen until they were weighed, freeze dried, and weighed again in the shorebased laboratory. In this study, bulk sedimentological and organic geochemical data are presented at $10-\mathrm{cm}$ spacings, corresponding to about 10 k.y., based on average mean sedimentation rates.

To document fluctuations in the relative proportions of the coarse $(>63 \mu \mathrm{m})$ and fine $(<63 \mu \mathrm{m})$ fraction of the bulk sediment, a sand record was performed at 10 -cm spacings for the upper $22 \mathrm{~m}$ of Hole 959C. To obtain coarse fraction contents, a split of the freeze-dried and weighed bulk samples was carefully washed over a $63-\mu \mathrm{m}$ mesh sieve. The dried coarse material was weighed again to determine the weight percent of a sand-sized fraction and then forwarded for further analysis, (i.e., for stable oxygen and carbon measurements; G.P. Lohmann, pers. comm., 1997). The residual fine material $(<63 \mu \mathrm{m}$ particle size) was collected and stored in $100-\mathrm{mL}$ plastic containers at $2^{\circ} \mathrm{C}$ in an ammonium-buffered demineralized water solution.

Organic and inorganic carbon were measured on homogenized samples using a Leco CS-300 elemental analyzer. For the determination of organic carbon, calcium carbonate was removed by repetitive addition of $0.25 \mathrm{~N} \mathrm{HCl}$. The carbonate content of the samples was calculated from the difference between total and organic carbon and expressed as calcite $\left[\mathrm{CaCO}_{3}=\left(\mathrm{C}_{\text {tot }}-\mathrm{C}_{\text {org }}\right) \times 8.33\right]$. To evaluate the reproducibility of carbon data, duplicates were routinely measured. Total nitrogen was measured on untreated samples using a Heraeus CHN-O-Rapid elemental analyzer, as described by Müller et al. (1994).

Qualitative characterization of sedimentary organic matter was derived from pyrolytic and elemental $\left(\mathrm{C}_{\mathrm{org}} / \mathrm{N}_{\text {tot }}\right)$ results. Quantitative data were obtained on a selected set of samples using (1) the isotopic record of the sedimentary organic carbon $\left(\delta^{13} C_{\text {org }}\right)$ and (2) results from maceral analysis (organic petrology). Whereas the calculation of marine vs. terrigenous proportions of organic carbon is well established for the $\delta^{13} \mathrm{C}_{\text {org }}$ records of the equatorial Atlantic (e.g. Müller et al., 1994; Schneider et al., 1996), there are no organic petrologic data published for unconsolidated deposits. The potential of organic petrologic studies on near-surface sediments, however, has been recently demonstrated in late Quaternary deposits of the Norwegian-Greenland Sea (Wagner, 1993; Wagner and Henrich, 1994; Hölemann and Henrich, 1994; Wagner and Hölemann, 1995) and in surface sediments of the North Sea (Wiesner et al., 1990).

Rock-Eval pyrolysis was performed on the total set of bulk samples using the standard analytical cycle described by Espitalié et al. (1977). For the thermally immature organic character of the unconsolidated samples of Hole 959C, hydrocarbons (HC) detected in the $\mathrm{S} 1$ window do not represent the oil fraction of thermally mature
Table 1. Level in core, age determination, source of datum, mean linear sedimentation rates, and mean accumulation rates for the uppermost 22 m of Hole 959C.

\begin{tabular}{rcccc}
\hline $\begin{array}{c}\text { Depth } \\
(\mathrm{mbsf})\end{array}$ & $\begin{array}{c}\text { Time } \\
(\mathrm{Ma})\end{array}$ & $\begin{array}{c}\text { Source of } \\
\text { datum }\end{array}$ & $\begin{array}{c}\text { LSR } \\
(\mathrm{cm} / \mathrm{k} . \mathrm{y} .)\end{array}$ & $\begin{array}{c}\text { AR bulk average } \\
\left(\mathrm{g} / \mathrm{cm}^{2} / \mathrm{k} . \mathrm{y} .\right)\end{array}$ \\
\hline 0.01 & 0.000 & CCC & 1.90 & 0.928 \\
0.41 & 0.021 & CCC & 0.96 & 0.675 \\
1.51 & 0.135 & CCC & 0.13 & 0.084 \\
1.64 & 0.234 & CCC & 1.23 & 0.785 \\
2.41 & 0.297 & CCC & 2.08 & 1.435 \\
3.41 & 0.345 & CCC & 1.22 & 0.831 \\
4.51 & 0.435 & CCC & 0.77 & 0.482 \\
4.81 & 0.474 & CN14b/CN14a & 2.31 & 1.498 \\
6.61 & 0.552 & CCC & 0.86 & 0.597 \\
7.31 & 0.633 & CCC & 0.89 & 0.635 \\
8.41 & 0.756 & CCC & 1.64 & 1.092 \\
11.01 & 0.915 & CCC & 1.21 & 0.822 \\
11.81 & 0.981 & CCC & 0.61 & 0.822 \\
11.91 & 1.533 & CCC & 0.00 & 0.000 \\
12.81 & 1.680 & CN14a/CN13b & 2.14 & 1.436 \\
17.81 & 1.914 & CCC & 1.70 & 1.190 \\
20.61 & 2.079 & CCC & 1.48 & 1.112 \\
21.01 & 2.106 & CCC & 1.48 & 1.113 \\
\hline
\end{tabular}

Notes: CCC $=$ core-to-core correlation. Stratigraphy according to G.P. Lohmann (pers. comm., 1997) and Shin et al. (Chap. 39, this volume).

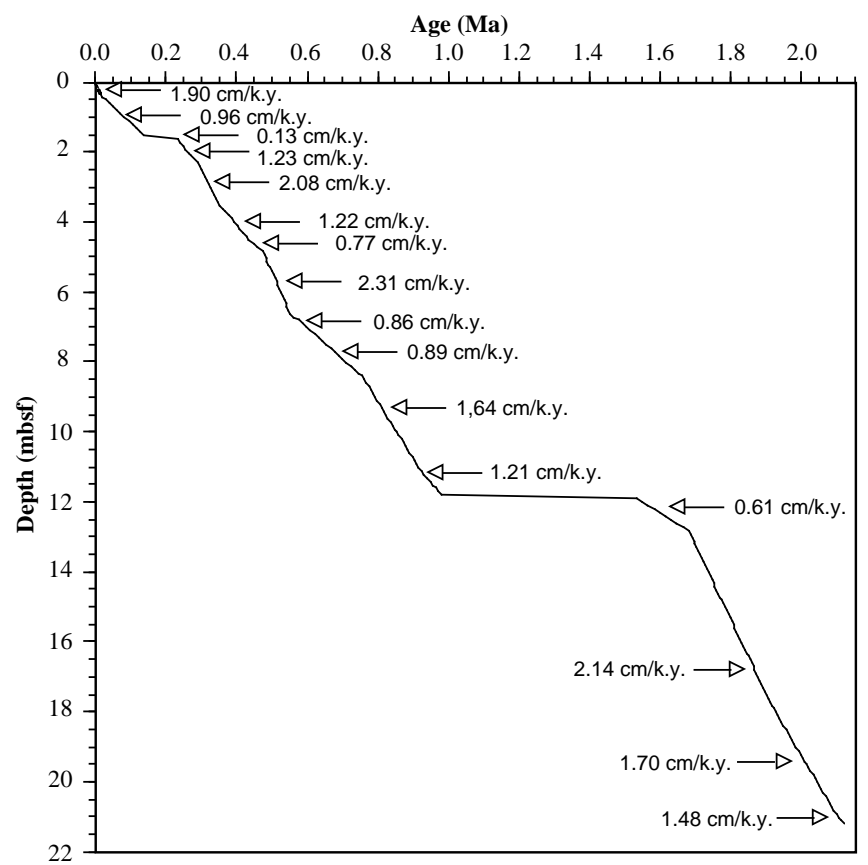

Figure 2. Age/depth plot for Hole 959C. Stratigraphic datums are taken from G.P. Lohmann (pers. comm., 1997) and Shin et al. (Chap. 39, this volume).

source rock sensu Espitalié et al. (1977), but potentially reflect HC generated from labile marine biopolymers (Liebezeit and Wiesner, 1989; Wagner and Henrich, 1994). HC detected in the S1 window were therefore added to the S2 (kerogen) yield before hydrogen indices (HI) were calculated (Tissot and Welte, 1984) using TOC values obtained from Leco analysis. Reduction of HC generation as a result of matrix adsorption (Katz, 1983) was estimated according to Langford and Blanc-Valleron (1990). The $\mathrm{S} 1+\mathrm{S} 2$ yield vs. TOC plot reveals a significant influence of mineral matrix adsorption, as indicated by an $\mathrm{x}$-intercept of $0.35 \%$ TOC on the regression line (Fig. 3). Hydrogen indices were therefore corrected using the equation $\mathrm{HI}=$ $[(\mathrm{S} 1+\mathrm{S} 2) \cdot 100] /(\mathrm{TOC}-0.35 \%)$.

Isotopic measurements of sedimentary organic carbon $\left(\delta^{13} \mathrm{C}_{\mathrm{org}}\right)$ were performed using a Finnigan MAT delta $\mathrm{E}$ mass spectrometer 
Table 2. Percentages of water content, bulk density, and porosity for the upper $22 \mathrm{~m}$ of Hole $959 \mathrm{C}$.

\begin{tabular}{|c|c|c|c|c|c|c|c|c|}
\hline $\begin{array}{l}\text { Core, section, } \\
\text { interval }(\mathrm{cm})\end{array}$ & $\begin{array}{l}\text { Depth } \\
\text { (mbsf) }\end{array}$ & $\begin{array}{c}\text { Water } \\
\text { content } \\
(\%)\end{array}$ & $\begin{array}{c}\text { Dry bulk } \\
\text { density } \\
\left(\mathrm{g} / \mathrm{cm}^{3}\right)\end{array}$ & $\begin{array}{l}\text { Porosity } \\
(\%)\end{array}$ & $\begin{array}{l}\text { Core, section, } \\
\text { interval }(\mathrm{cm})\end{array}$ & $\begin{array}{l}\text { Depth } \\
\text { (mbsf) }\end{array}$ & $\begin{array}{c}\text { Water } \\
\text { content } \\
(\%)\end{array}$ & $\begin{array}{c}\text { Dry bulk } \\
\text { density } \\
\left(\mathrm{g} / \mathrm{cm}^{3}\right)\end{array}$ \\
\hline 159-959C- & & & & & $2 \mathrm{H}-5,92.5-95.0$ & 9.24 & 49.38 & 0.75 \\
\hline $1 \mathrm{H}-1,2.5-5.0$ & 0.04 & 67.14 & 0.43 & 83.62 & $2 \mathrm{H}-5,102.5-105.0$ & 9.34 & 56.60 & 0.61 \\
\hline $1 \mathrm{H}-1,12.5-15.0$ & 0.14 & 65.87 & 0.45 & 82.88 & $2 \mathrm{H}-5,112.5-115.0$ & 9.44 & 54.00 & 0.66 \\
\hline $1 \mathrm{H}-1,22.5-25.0$ & 0.24 & 57.02 & 0.60 & 77.25 & $2 \mathrm{H}-5,122.5-125.0$ & 9.54 & 54.57 & 0.65 \\
\hline $1 \mathrm{H}-1,42.5-45.0$ & 0.44 & 54.83 & 0.64 & 75.73 & $2 \mathrm{H}-5,132.5-135.0$ & 9.64 & 53.20 & 0.67 \\
\hline $1 \mathrm{H}-1,52.5-5.0$ & 0.54 & 49.87 & 0.74 & 72.04 & $2 \mathrm{H}-5,142.5-145.0$ & 9.74 & 54.02 & 0.66 \\
\hline $1 \mathrm{H}-1,62.5-65.0$ & 0.64 & 50.30 & 0.73 & 72.37 & $2 \mathrm{H}-6,2.5-5.0$ & 9.84 & 56.50 & 0.61 \\
\hline $1 \mathrm{H}-1,72.5-75.0$ & 0.74 & 50.50 & 0.73 & 72.53 & $2 \mathrm{H}-6,12.5-15.0$ & 9.94 & 54.52 & 0.65 \\
\hline $1 \mathrm{H}-1,82.5-85.0$ & 0.84 & 49.49 & 0.75 & 71.74 & $2 \mathrm{H}-6,22.5-25.0$ & 10.04 & 54.34 & 0.65 \\
\hline $1 \mathrm{H}-1,92.5-95.0$ & $\begin{array}{l}0.04 \\
0.94\end{array}$ & 51.35 & 0.71 & 73.18 & $2 \mathrm{H}-6,32.5-35.0$ & 10.14 & 53.27 & 0.67 \\
\hline $1 \mathrm{H}-1,102.5-105.0$ & 1.04 & 51.12 & 0.72 & 73.00 & $2 \mathrm{H}-6,42.5-45.0$ & 10.24 & 52.29 & 0.69 \\
\hline $1 \mathrm{H}-1,112.5-115.0$ & 1.14 & 52.49 & 0.69 & 74.03 & $2 \mathrm{H}-6,52.5-55.0$ & 10.34 & 51.46 & 0.71 \\
\hline $1 \mathrm{H}-1,122.5-125.0$ & 1.24 & 54.01 & 0.66 & 75.14 & $2 \mathrm{H}-6,62.5-65.0$ & 10.44 & 53.01 & 0.68 \\
\hline $1 \mathrm{H}-1,132.5-135.0$ & 1.34 & 51.83 & 0.70 & 73.53 & $2 \mathrm{H}-6,72.5-75.0$ & 10.54 & 54.57 & 0.65 \\
\hline $1 \mathrm{H}-1,142.5-145.0$ & 1.44 & 55.65 & 0.63 & 76.30 & $2 \mathrm{H}-6,82.5-85.0$ & 10.64 & 51.41 & 0.71 \\
\hline $1 \mathrm{H}-2,2.5-5.0$ & 1.54 & 53.84 & 0.66 & 75.02 & $2 \mathrm{H}-6,92.5-95.0$ & 10.74 & 54.14 & 0.66 \\
\hline $1 \mathrm{H}-2,22.5-25.0$ & $\begin{array}{l}1.54 \\
1.74\end{array}$ & $\begin{array}{l}53.84 \\
58.01\end{array}$ & $\begin{array}{l}0.59 \\
0.59\end{array}$ & $\begin{array}{l}15.02 \\
77.92\end{array}$ & $2 \mathrm{H}-6,102.5-105.0$ & 10.84 & 51.65 & 0.70 \\
\hline $1 \mathrm{H}-2,32.5-35.0$ & 1.84 & 54.37 & 0.65 & 75.40 & $2 \mathrm{H}-6,112.5-115.0$ & 10.94 & 52.50 & 0.69 \\
\hline $1 \mathrm{H}-2,42.5-45.0$ & 1.94 & 51.83 & 0.70 & 73.54 & $2 \mathrm{H}-6,122.5-125.0$ & 11.04 & 54.23 & 0.65 \\
\hline $1 \mathrm{H}-2,52.5-55.0$ & 2.04 & 55.14 & 0.64 & 75.95 & $2 \mathrm{H}-6,132.5-135.0$ & 11.14 & 55.63 & 0.63 \\
\hline $1 \mathrm{H}-2,62.5-65.0$ & 2.14 & $\begin{array}{l}54.69 \\
\end{array}$ & 0.65 & 75.63 & $2 \mathrm{H}-6,142.5-145.0$ & 11.24 & 54.25 & 0.65 \\
\hline $2 \mathrm{H}-1,2.5-5.0$ & 2.34 & 56.43 & 0.61 & 76.85 & $2 \mathrm{H}-7,2.5-5.0$ & 11.34 & 54.01 & 0.66 \\
\hline $2 \mathrm{H}-1,12.5-15.0$ & 2.44 & 53.00 & 0.68 & 74.41 & $2 \mathrm{H}-7,12.5-15.0$ & 11.44 & 51.83 & 0.70 \\
\hline $2 \mathrm{H}-1,22.5-25.0$ & 2.54 & 47.59 & 0.79 & 70.23 & $2 \mathrm{H}-7,22.5-25.0$ & 11.54 & 52.16 & 0.69 \\
\hline $2 \mathrm{H}-1,32.5-35.0$ & 2.64 & 55.73 & 0.63 & 76.36 & $2 \mathrm{H}-7,32.5-35.0$ & 11.64 & 52.68 & 0.68 \\
\hline $2 \mathrm{H}-1,42.5-45.0$ & 2.74 & 54.68 & 0.65 & 75.62 & $2 \mathrm{H}-7,42.5-45.0$ & 11.74 & 52.49 & 0.69 \\
\hline $2 \mathrm{H}-1,52.5-55.0$ & 2.84 & 54.59 & 0.65 & 75.56 & $2 \mathrm{H}-7,52.5-55.0$ & 11.84 & 49.88 & 0.74 \\
\hline $2 \mathrm{H}-1,62.5-65.0$ & $\begin{array}{l}2.04 \\
2.94\end{array}$ & 50.92 & 0.72 & 72.85 & $2 \mathrm{H}-7,62.5-65.0$ & $\begin{array}{l}11.04 \\
11.94\end{array}$ & 53.90 & 0.66 \\
\hline $2 \mathrm{H}-1,72.5-75.0$ & 3.04 & 54.62 & 0.65 & 75.58 & $3 \mathrm{H}-1,2.5-5.0$ & 11.84 & 59.45 & 0.56 \\
\hline $2 \mathrm{H}-1,82.5-85.0$ & 3.14 & 53.46 & 0.67 & 74.74 & $3 \mathrm{H}-1,12.5-15.0$ & 11.94 & 57.56 & 0.59 \\
\hline $2 \mathrm{H}-1,92.5-95.0$ & 3.24 & 52.52 & 0.69 & 74.05 & $3 \mathrm{H}-1,22.5-25.0$ & 12.04 & 56.87 & 0.61 \\
\hline $2 \mathrm{H}-1,102.5-105.0$ & 3.34 & 48.19 & 0.78 & 70.72 & $3 \mathrm{H}-1,32.5-35.0$ & 12.14 & 57.33 & 0.60 \\
\hline $2 \mathrm{H}-1,112.5-115.0$ & 3.44 & 51.20 & 0.71 & 73.06 & $3 \mathrm{H}-1,42.5-45.0$ & 12.24 & 58.18 & 0.58 \\
\hline $2 \mathrm{H}-1,122.5-125.0$ & 3.54 & 51.58 & 0.71 & 73.35 & $3 \mathrm{H}-1,52.5-55.0$ & 12.34 & $\begin{array}{l}30.10 \\
53.10\end{array}$ & 0.68 \\
\hline $2 \mathrm{H}-1,132.5-135.0$ & 3.64 & 51.43 & 0.71 & 73.24 & $3 \mathrm{H}-1,62.5-65.0$ & 12.44 & 56.15 & 0.62 \\
\hline $2 \mathrm{H}-1,142.5-145.0$ & 3.74 & 51.15 & 0.71 & 73.02 & $3 \mathrm{H}-1,72.5-75.0$ & 12.54 & 54.02 & 0.66 \\
\hline $2 \mathrm{H}-2,2.5-5.0$ & 3.84 & 52.66 & 0.68 & 74.16 & $3 \mathrm{H}-1,82.5-85.0$ & 12.64 & 47.64 & 0.79 \\
\hline $2 \mathrm{H}-2,22.5-25.0$ & 4.04 & 53.86 & 0.66 & 75.03 & $3 \mathrm{H}-1,92.5-95.0$ & 12.74 & 50.40 & 0.73 \\
\hline $2 \mathrm{H}-2,32.5-35.0$ & 4.14 & $\begin{array}{l}56.00 \\
56.29\end{array}$ & 0.62 & 76.75 & $3 \mathrm{H}-1,102.5-105.0$ & 12.84 & 52.18 & 0.69 \\
\hline $2 \mathrm{H}-2,42.5-45.0$ & $\begin{array}{l}4.14 \\
4.24\end{array}$ & $\begin{array}{l}3.29 \\
53.75\end{array}$ & $\begin{array}{l}0.02 \\
0.66\end{array}$ & 74.95 & $3 \mathrm{H}-1,112.5-115.0$ & $\begin{array}{l}12.84 \\
12.94\end{array}$ & 51.77 & $\begin{array}{l}.09 \\
0.70\end{array}$ \\
\hline $2 \mathrm{H}-2,52.5-55.0$ & 4.34 & 53.01 & 0.68 & 74.41 & $3 \mathrm{H}-1,122.5-125.0$ & 13.04 & 56.87 & 0.61 \\
\hline $2 \mathrm{H}-2,62.5-65.0$ & 4.44 & 54.09 & 0.66 & 75.20 & $3 \mathrm{H}-1,132.5-135.0$ & 13.14 & 55.33 & 0.63 \\
\hline $2 \mathrm{H}-2,72.5-75.0$ & 4.54 & 55.18 & 0.64 & 75.98 & $3 \mathrm{H}-1,142.5-145.0$ & 13.24 & 54.56 & 0.65 \\
\hline $2 \mathrm{H}-2,82.5-85.0$ & 4.64 & 56.34 & 0.62 & 76.78 & $3 \mathrm{H}-2,2.5-5.0$ & 13.34 & 53.77 & 0.66 \\
\hline $2 \mathrm{H}-2,92.5-95.0$ & 4.74 & 55.66 & 0.63 & 76.31 & $3 \mathrm{H}-2,12.5-15.0$ & 13.44 & 54.10 & 0.66 \\
\hline $2 \mathrm{H}-2,102.5-105.0$ & $\begin{array}{l}4.14 \\
4.84\end{array}$ & $\begin{array}{l}34.00 \\
54.80\end{array}$ & $\begin{array}{l}0.03 \\
0.64\end{array}$ & $\begin{array}{l}10.31 \\
75.70\end{array}$ & $3 \mathrm{H}-2,22.5-25.0$ & $\begin{array}{l}13.44 \\
13.54\end{array}$ & 51.05 & $\begin{array}{l}.00 \\
0.72\end{array}$ \\
\hline $2 \mathrm{H}-2,112.5-115.0$ & 4.94 & 56.93 & 0.60 & 77.19 & $3 \mathrm{H}-2,32.5-35.0$ & 13.64 & 51.69 & 0.70 \\
\hline $2 \mathrm{H}-2,122.5-125.0$ & 5.04 & 57.50 & 0.59 & 77.58 & $3 \mathrm{H}-2,42.5-45.0$ & 13.74 & 56.60 & 0.61 \\
\hline $2 \mathrm{H}-2,132.5-135.0$ & 5.14 & 53.06 & 0.68 & 74.45 & $3 \mathrm{H}-2,52.5-55.0$ & 13.84 & 48.87 & 0.76 \\
\hline $2 \mathrm{H}-2,142.5-145.0$ & 5.24 & 55.73 & 0.63 & 76.37 & $3 \mathrm{H}-2,62.5-65.0$ & 13.94 & 56.23 & 0.62 \\
\hline $2 \mathrm{H}-3,2.5-5.0$ & 5.34 & 56.17 & 0.62 & 76.67 & $3 \mathrm{H}-2,72.5-75.0$ & 14.04 & 53.81 & 0.66 \\
\hline $2 \mathrm{H}-3,12.5-15.0$ & 5.44 & 56.84 & 0.61 & 77.13 & $3 \mathrm{H}-2,82.5-85.0$ & 14.14 & 56.03 & 0.62 \\
\hline $2 \mathrm{H}-3,22.5-25.0$ & 5.54 & 56.25 & 0.62 & 76.73 & $3 \mathrm{H}-2,102.5-105.0$ & 14.34 & 53.61 & 0.67 \\
\hline $2 \mathrm{H}-3,32.5-35.0$ & 5.64 & 54.22 & 0.65 & 75.29 & $3 \mathrm{H}-2,112.5-115.0$ & 14.44 & 54.60 & 0.65 \\
\hline $2 \mathrm{H}-3,42.5-45.0$ & 5.74 & 52.55 & 0.69 & 74.07 & $3 \mathrm{H}-2,122.5-125.0$ & 14.54 & 55.15 & 0.64 \\
\hline $2 \mathrm{H}-3,52.5-55.0$ & 5.84 & 56.04 & 0.62 & 76.58 & $3 \mathrm{H}-2,132.5-35.0$ & 14.64 & 58.76 & 0.57 \\
\hline $2 \mathrm{H}-3,62.5-65.0$ & 5.94 & 55.45 & 0.63 & 76.17 & $3 \mathrm{H}-2,142.5-145.0$ & 14.74 & 55.02 & 0.64 \\
\hline $2 \mathrm{H}-3,72.5-75.0$ & 6.04 & 49.59 & 0.75 & 71.82 & $3 \mathrm{H}-3,2.5-5.0$ & 14.84 & 51.87 & 0.70 \\
\hline $2 \mathrm{H}-3,82.5-85.0$ & $\begin{array}{l}6.04 \\
6.14\end{array}$ & $\begin{array}{l}49.59 \\
51.95\end{array}$ & 0.70 & $\begin{array}{l}1.02 \\
73.62\end{array}$ & $3 \mathrm{H}-3,22.5-25.0$ & $\begin{array}{l}15.04 \\
15.04\end{array}$ & 52.98 & 0.68 \\
\hline $2 \mathrm{H}-3,92.5-95.0$ & 6.24 & 52.57 & 0.69 & 74.09 & $3 \mathrm{H}-3,32.5-35.0$ & 15.14 & 52.56 & $\begin{array}{l}0.00 \\
0.69\end{array}$ \\
\hline $2 \mathrm{H}-3,102.5-105.0$ & 6.34 & 53.51 & 0.67 & 74.78 & $3 \mathrm{H}-3,42.5-45.0$ & 15.24 & 54.92 & 0.64 \\
\hline $2 \mathrm{H}-3,112.5-115.0$ & 6.44 & 55.63 & 0.63 & 76.29 & $3 \mathrm{H}-5,52.5-14.8$ & 15.34 & 56.17 & 0.62 \\
\hline $2 \mathrm{H}-3,122.5-125.0$ & 6.54 & 53.37 & 0.67 & 74.67 & $3 \mathrm{H}-3,62.5-65.0$ & 15.44 & 56.17 & 0.62 \\
\hline $2 \mathrm{H}-3,132.5-135.0$ & 6.64 & 52.82 & 0.68 & 74.27 & $3 \mathrm{H}-3,72.5-75.0$ & 15.54 & 54.76 & 0.64 \\
\hline $2 \mathrm{H}-3,142.5-145.0$ & 6.74 & 52.78 & 0.68 & 74.25 & $3 \mathrm{H}-3,82.5-85.0$ & 15.64 & 53.28 & 0.67 \\
\hline $2 \mathrm{H}-4,2.5-5.0$ & $\begin{array}{l}0.14 \\
6.84\end{array}$ & 52.66 & $\begin{array}{l}0.68 \\
0.68\end{array}$ & 74.16 & $3 \mathrm{H}-3,102.5-105.0$ & 15.84 & 53.70 & 0.66 \\
\hline $2 \mathrm{H}-4,12.5-15.0$ & 6.94 & 53.62 & 0.67 & 74.8 & $3 \mathrm{H}-3,112.5-115.0$ & 15.94 & 51.61 & 0.71 \\
\hline $2 \mathrm{H}-4,22.5-25.0$ & 7.04 & 53.51 & 0.67 & 74.78 & $3 \mathrm{H}-3,122.5-125.0$ & 16.04 & 53.97 & 0.66 \\
\hline $2 \mathrm{H}-4,32.5-35.0$ & 7.14 & 52.17 & 0.69 & $\begin{array}{l}73.79 \\
73.79\end{array}$ & $3 \mathrm{H}-3,132.5-135.0$ & 16.14 & 53.61 & 0.67 \\
\hline $2 \mathrm{H}-4,42.5-45.0$ & $\begin{array}{l}1.14 \\
7.24\end{array}$ & 48.88 & $\begin{array}{l}0.09 \\
0.76\end{array}$ & 71.26 & $3 \mathrm{H}-3,142.5-145.0$ & $\begin{array}{l}16.14 \\
16.24\end{array}$ & 51.95 & $\begin{array}{l}0.01 \\
0.70\end{array}$ \\
\hline $2 \mathrm{H}-4,52.5-55.0$ & 7.34 & 50.75 & 0.72 & 72.72 & $3 \mathrm{H}-4,2.5-5.0$ & 16.34 & 49.65 & 0.75 \\
\hline $2 \mathrm{H}-4,62.5-65.0$ & 7.44 & 48.53 & 0.77 & 70.99 & $3 \mathrm{H}-4,22.5-25.0$ & 16.54 & 51.03 & 0.72 \\
\hline $2 \mathrm{H}-4,72.5-75.0$ & 7.54 & 50.11 & 0.74 & 72.23 & $3 \mathrm{H}-4,32.5-35.0$ & 16.64 & 53.75 & 0.66 \\
\hline $2 \mathrm{H}-4,82.5-85.0$ & 7.64 & 53.41 & 0.67 & 74.71 & $3 \mathrm{H}-4,42.5-45.0$ & 16.74 & 54.88 & 0.64 \\
\hline $2 \mathrm{H}-4,92.5-95.0$ & 7.74 & 53.26 & 0.67 & $\begin{array}{l}74.60 \\
74.60\end{array}$ & $3 \mathrm{H}-4,52.5-55.0$ & 16.84 & 54.36 & 0.65 \\
\hline $2 \mathrm{H}-4,102.5-105.0$ & 7.84 & 52.92 & 0.68 & 74.35 & $3 \mathrm{H}-4,62.5-65.0$ & 16.94 & 51.71 & 0.70 \\
\hline $2 \mathrm{H}-4,112.5-115.0$ & 7.94 & 54.80 & 0.64 & 75.70 & $3 \mathrm{H}-4,72.5-75.0$ & 17.04 & 52.81 & 0.68 \\
\hline $2 \mathrm{H}-4,122.5-125.0$ & 8.04 & 51.35 & 0.71 & 73.17 & $3 \mathrm{H}-4,82.5-85.0$ & 17.14 & 53.15 & $\begin{array}{l}0.00 \\
0.68\end{array}$ \\
\hline $2 \mathrm{H}-4,132.5-135.0$ & 8.14 & 53.63 & 0.67 & 74.87 & $3 \mathrm{H}-4,92.5-95.0$ & 17.24 & 54.25 & 0.65 \\
\hline $2 \mathrm{H}-4,142.5-145.0$ & 8.24 & 47.59 & 0.79 & 70.23 & $3 \mathrm{H}-4,102.5-105.0$ & 17.34 & 52.14 & 0.70 \\
\hline $2 \mathrm{H}-5,2.5-5.0$ & $\begin{array}{l}0.24 \\
8.34\end{array}$ & 49.23 & 0.75 & 71.54 & $3 \mathrm{H}-4,112.5-115.0$ & 17.44 & 48.65 & 0.77 \\
\hline $2 \mathrm{H}-5,12.5-15.0$ & 8.44 & 47.34 & 0.79 & 70.03 & $3 \mathrm{H}-4,122.5-125.0$ & 17.54 & 51.41 & 0.71 \\
\hline $2 \mathrm{H}-5,22.5-25.0$ & 8.54 & 51.15 & 0.71 & 73.02 & $3 \mathrm{H}-4,132.5-135.0$ & 17.64 & 51.56 & 0.71 \\
\hline $2 \mathrm{H}-5,32.5-35.0$ & 8.64 & 52.29 & 0.69 & 73.88 & $3 \mathrm{H}-4,142.5-145.0$ & 17.74 & 50.32 & 0.73 \\
\hline $2 \mathrm{H}-5,42.5-45.0$ & 8.74 & 53.81 & 0.66 & 75.00 & $3 \mathrm{H}-5,2.5-5.0$ & 17.84 & 51.34 & 0.71 \\
\hline $2 \mathrm{H}-5,52.5-55.0$ & 8.84 & 59.37 & 0.56 & 78.83 & $3 \mathrm{H}-5,12.5-15.0$ & 17.94 & 51.00 & 0.72 \\
\hline $2 \mathrm{H}-5,62.5-65.5$ & $\begin{array}{l}.04 \\
8.94\end{array}$ & 55.36 & 0.63 & $\begin{array}{l}10.03 \\
76.10\end{array}$ & $3 \mathrm{H}-5,22.5-25.0$ & 18.04 & 49.81 & 0.74 \\
\hline $2 \mathrm{H}-5,72.5-75.0$ & $\begin{array}{l}8.94 \\
9.04\end{array}$ & 56.54 & $\begin{array}{l}0.03 \\
0.61\end{array}$ & $\begin{array}{l}10.10 \\
76.92\end{array}$ & $3 \mathrm{H}-5,32.5-35.0$ & $\begin{array}{l}18.04 \\
18.14\end{array}$ & $\begin{array}{l}49.81 \\
51.02\end{array}$ & $\begin{array}{l}0.14 \\
0.72\end{array}$ \\
\hline $2 \mathrm{H}-5,82.5-85.0$ & 9.14 & 56.31 & 0.62 & 76.76 & $3 \mathrm{H}-5,42.5-45.0$ & 18.24 & 50.72 & 0.72 \\
\hline
\end{tabular}


Table 2 (continued).

\begin{tabular}{ccccc}
\hline $\begin{array}{c}\text { Core, section, } \\
\text { interval (cm) }\end{array}$ & $\begin{array}{c}\text { Depth } \\
\text { (mbsf) }\end{array}$ & $\begin{array}{c}\text { Water } \\
\text { content } \\
(\%)\end{array}$ & $\begin{array}{c}\text { Dry bulk } \\
\text { density } \\
\left(\mathrm{g} / \mathrm{cm}^{3}\right)\end{array}$ & $\begin{array}{c}\text { Porosity } \\
(\%)\end{array}$ \\
\hline 3H-5, 52.5-55.0 & 18.34 & 50.15 & 0.74 & 72.25 \\
3H-5, 62.5-65.0 & 18.44 & 52.69 & 0.68 & 74.18 \\
3H-5, 72.5-75.0 & 18.54 & 52.73 & 0.68 & 74.20 \\
3H-5, 82.5-85.0 & 18.64 & 53.15 & 0.68 & 74.52 \\
3H-5, 92.5-95.0 & 18.74 & 53.16 & 0.68 & 74.53 \\
3H-5, 102.5-105.0 & 18.84 & 53.57 & 0.67 & 74.82 \\
3H-5, 112.5-115.0 & 18.94 & 54.01 & 0.66 & 75.14 \\
3H-5, 122.5-125.0 & 19.04 & 51.20 & 0.71 & 73.06 \\
3H-5, 132.5-135.0 & 19.14 & 52.61 & 0.69 & 74.12 \\
3H-5, 142.5-145.0 & 19.24 & 50.13 & 0.74 & 72.25 \\
3H-6, 2.5-5.0 & 19.34 & 51.98 & 0.70 & 73.65 \\
3H-6, 12.5-15.0 & 19.44 & 52.49 & 0.69 & 74.03 \\
3H-6, 22.5-25.0 & 19.54 & 53.08 & 0.68 & 74.46 \\
3H-6, 32.5-35.0 & 19.64 & 52.68 & 0.68 & 74.17 \\
3H-6, 42.5-45.0 & 19.74 & 52.10 & 0.70 & 73.74 \\
3H-6, 52.5-55.0 & 19.84 & 51.62 & 0.71 & 73.38 \\
3H-6, 62.5-65.0 & 19.94 & 52.28 & 0.69 & 73.88 \\
3H-6, 72.5-75.0 & 20.04 & 52.43 & 0.69 & 73.99 \\
3H-6, 82.5-85.0 & 20.14 & 52.81 & 0.68 & 74.26 \\
3H-6, 92.5-95.0 & 20.24 & 52.52 & 0.69 & 74.05 \\
3H-6, 102.5-105.0 & 20.34 & 51.13 & 0.72 & 73.01 \\
3H-6, 112.5-115.0 & 20.44 & 50.78 & 0.72 & 72.74 \\
3H-6, 122.5-125.0 & 20.54 & 48.46 & 0.77 & 70.93 \\
3H-6, 132.5-135.0 & 20.64 & 47.98 & 0.78 & 70.55 \\
3H-6, 142.5-145.0 & 20.74 & 48.18 & 0.78 & 70.71 \\
3H-7, 2.5-5.0 & 20.84 & 48.19 & 0.78 & 70.71 \\
3H-7, 12.5-15.0 & 20.94 & 52.09 & 0.70 & 73.73 \\
3H-7, 22.5-25.0 & 21.04 & 50.34 & 0.73 & 72.41 \\
3H-7, 32.5-35.0 & 21.14 & 50.23 & 0.73 & 72.32 \\
3H-7, 42.5-45.0 & 21.24 & 47.55 & 0.79 & 70.19 \\
\hline
\end{tabular}

and a Heraeus CHN-Rapid elemental analyzer interfaced by an automated trapping box. Samples were prepared as described for TOC measurements. The amount of marine organic carbon was calculated using a simple mixing equation between the two end-members of $18 \%$ and $-27 \%$ or marine and terrigenous organic matter, respectively.

Organic petrologic analysis was performed on bulk sediment samples using a Zeiss Axiophot equipped with incident normal and ultraviolet light. Organic petrology may provide important quantitative data on the composition of sedimentary organic matter because more than $80 \%$ of the total organic matter occurs in the form of discrete, optical, resolvable particles (Littke, 1993). Thoroughly crushed bulk sediment samples were embedded under vacuum conditions in a low-viscous resin, then stored for at least two days before the specimen surface was ground and polished. Influence of mechanical fragmentation of organic particles during sample preparation on organic petrologic results can be disregarded because microscopic investigations were exclusively performed on undisturbed sediment pellets. Organic particle identification was conducted at 500- and 1000-fold magnification using both normal and ultraviolet light mode. Individual macerals (250) were counted as grain\% of the whole maceral composition on each sample, following the standard nomenclature of Stach et al. (1982). Some modifications concerning the group of marine macerals were necessary to obtain a more useful classification for the sediments studied. Alginite sensu Stach et al. (1982) was not observed. Instead, dinoflagellate cysts and fragments of them $(<10$ $\mu \mathrm{m}$, liptodetrinite of marine origin) represent the most common and well-preserved indicators of past export production and were therefore counted as marine alginite. Other organic particles of possible marine origin, for example bituminite, foraminifer linings or fluorescent amorphous organic matter (AOM) also occur. Considering the general concerns of quantitative data based on microscopic results, some principal methodological limitations have to be considered: (1) Separation of fluorescent fragments of marine (alginite) and terrestrial (sporinite, cutinite) macerals; (2) identification of lateral advected marine organic particles; and (3) distinguishing of highly reflecting detrital inertinite and small-sized mineral grains (Combaz et al., 1974). In addition, differences in size and average density of organic particles have to be taken into account, especially if macerals cover a

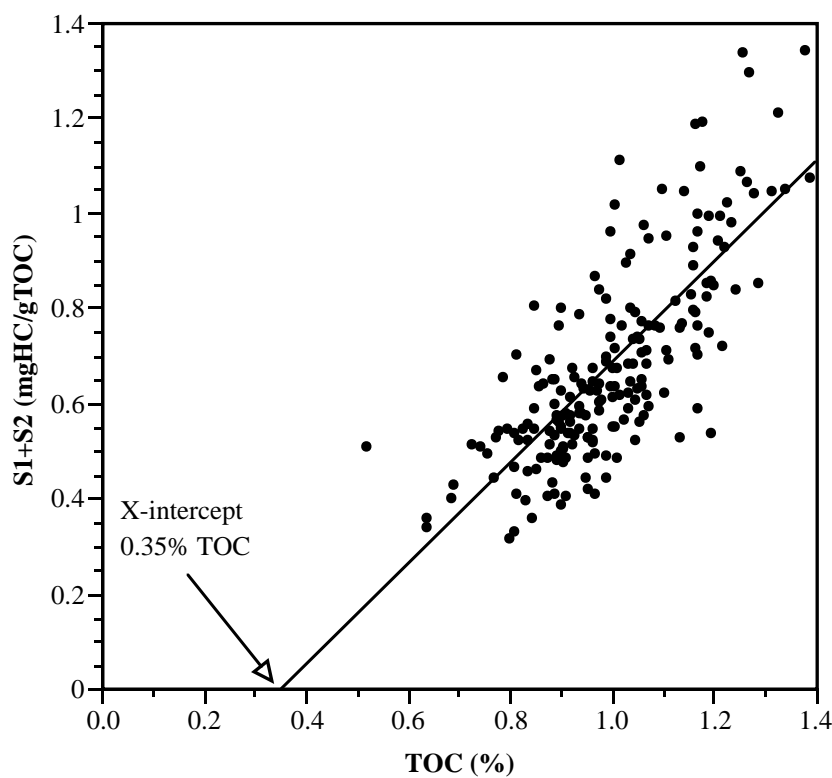

Figure 3. Graphic presentation of $\mathrm{S} 1+\mathrm{S} 2$ yields vs. total organic carbon (TOC) of Rock-Eval data from Hole 959C (modified after Langford and Blanc-Valleron, 1990). The $\mathrm{x}$-intercept of the regression line at $0.35 \%$ TOC indicates an intense influence of mineral-matrix effects on Pliocene-Pleistocene samples.

broad range of small and large particles. Factors may compensate for the different particle sizes. Their application, however, becomes more important the higher the proportion of larger organic particles are. Organic matter observed in sediments of Hole 959C is clearly dominated by very small particle sizes $(<10 \mu \mathrm{m}$, detrinite) revealing on average $80 \%$ of the total maceral composition (see discussion below). The relative precision of microscopic results, based on duplicate countings, was below $5 \%$. To avoid any artifact produced by the application of factors, no correction for particle sizes was conducted on Hole 959C samples. The inaccuracy of microscopic data might generally result in a minor overestimation of the marine proportion of sedimentary OM.

\section{RESULTS}

\section{Pliocene-Pleistocene Variations in Physical Properties, Mean Linear Sedimentation Rates, and Mean Accumulation Rates}

The calculated water content, porosity, and dry bulk density (DBD) records for the upper $22 \mathrm{~m}$ of Hole 959C are presented at 10$\mathrm{cm}$ spacings in Figure 4. Additional physical property data performed shipboard on depth-equivalent sections of Hole 959A indicate a fairly good hole-to-hole correlation for the upper half of the record, taking the different position and sampling resolution in account. Variations in physical properties, which are probably related to glacial/interglacial changes in the composition of lithologies, are most obvious in the upper $10 \mathrm{~m}$ of Hole 959C. Minor fluctuations in all three parameters are commonly reflected by slight variations in sediment color and the occurrence of laminated intervals observed during shipboard core description (Mascle, Lohmann, Clift, et al., 1996). Intervals enriched in foraminifers were recognized in the alternating sequence of dark gray-green to gray nannofossil oozes with foraminifers, and foraminifer-nannofossil oozes of Hole 959C (see shipboard core description by Mascle, Lohmann, Clift, et al., 1996) and are generally characterized by elevated DBD (Fig. 4) and, even more obviously, by peak coarse fraction and bulk carbonate contents. The drastic decrease in DBD in the uppermost $50 \mathrm{~cm}$ of Hole 959C documents the watersaturated top of the unconsolidated sedimentary column, which 


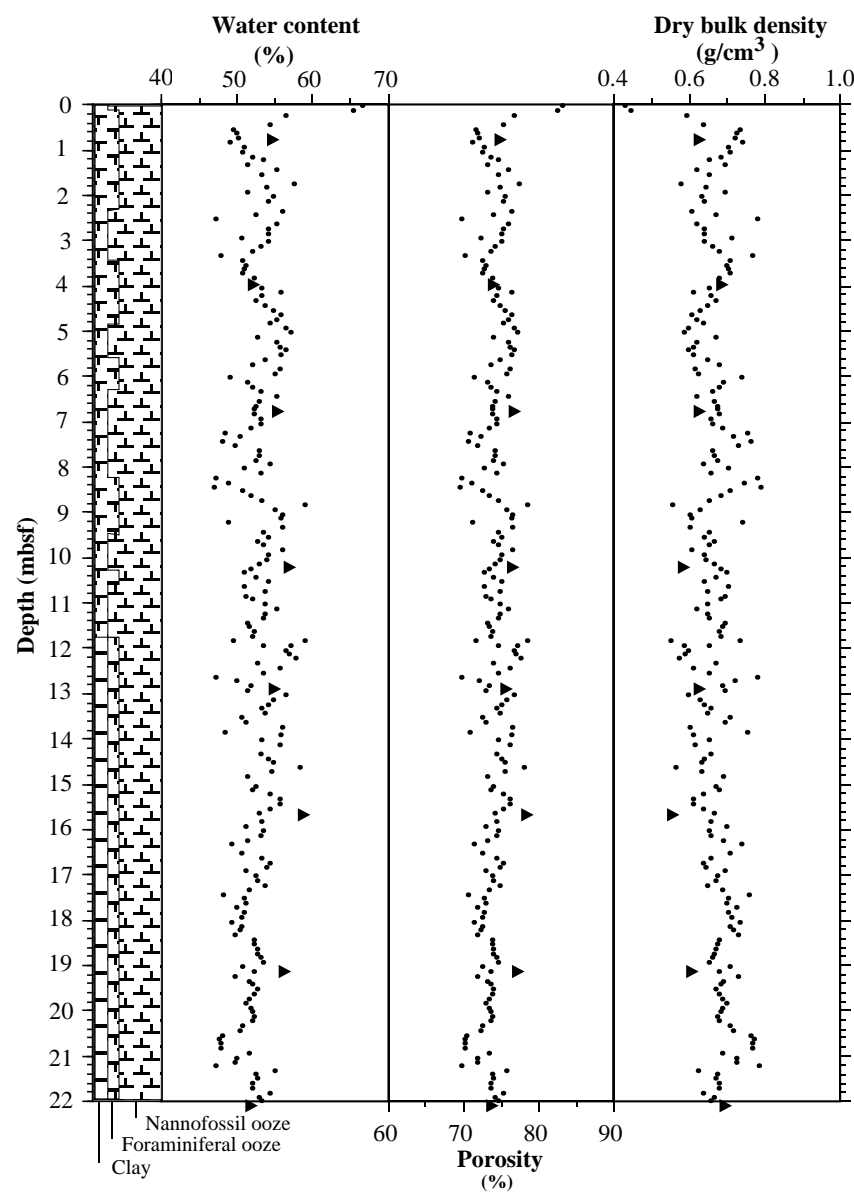

Figure 4. Water content, porosity, and dry bulk density of the upper $22 \mathrm{~m}$ of Hole 959C vs. sub-bottom depth. Hole 959A shipboard data are indicated by triangles for comparison. Lithology is shown for illustration (modified from Mascle, Lohmann, Clift, et al., 1996).

seems to be heavily influenced by drilling-induced disturbance of the sediments. Additional evidence for disturbance of the sediment surface is derived from sedimentological, organic geochemical, and isotopic data.

Based on the first stratigraphic model established for PliocenePleistocene sections of Hole 959C, mean linear sedimentation rates (LSR) and corresponding average mean accumulation rates (AR) remain continuously low, scattering from 0.1 to $2.3 \mathrm{~cm} / \mathrm{k}$.y. and 0.08 to $1.50 \mathrm{~g} / \mathrm{cm}^{2} / \mathrm{k}$.y., respectively (Fig. 5). Given the variable density of stratigraphic fixpoints between the time intervals $2.2-1.55 \mathrm{Ma}$ and 1.0-0.0 Ma, elevated LSR and AR exceeding $1.5 \mathrm{~cm} / \mathrm{k} . \mathrm{y}$. and $1.0 \mathrm{~g} /$ $\mathrm{cm}^{2} / \mathrm{k}$.y., respectively, appear typical prior to $1.68 \mathrm{Ma}$, followed by a drastic drop in both parameters. Younger core intervals in general show low levels in LSR and AR, except for the time intervals between 0.52 to $0.47 \mathrm{Ma}, 0.35$ to $0.30 \mathrm{Ma}$, and 0.02 to $0.00 \mathrm{Ma}$, where rates reach comparable values, as in the lowermost core section prior to $1.68 \mathrm{Ma}$. The corresponding average mean AR for carbonate carbon and organic carbon closely follow the LSR and bulk AR records. Calculated mean AR for individual components range from 0.1 to $0.85 \mathrm{~g} / \mathrm{cm}^{2} / \mathrm{k}$.y. and from almost zero to $0.02 \mathrm{~g} / \mathrm{cm}^{2} / \mathrm{k}$.y., respectively (Fig. 5).

\section{The Pliocene-Pleistocene Sand and Carbonate Record}

Weight-percentage records of coarse fraction $(>63 \mu \mathrm{m})$ and bulk calcium carbonate vs. depth and time are shown for PliocenePleistocene sections of Hole 959C in Figures 6 and 7 and are listed in Table 3 . Sand and carbonate values overall correlate positive and re-

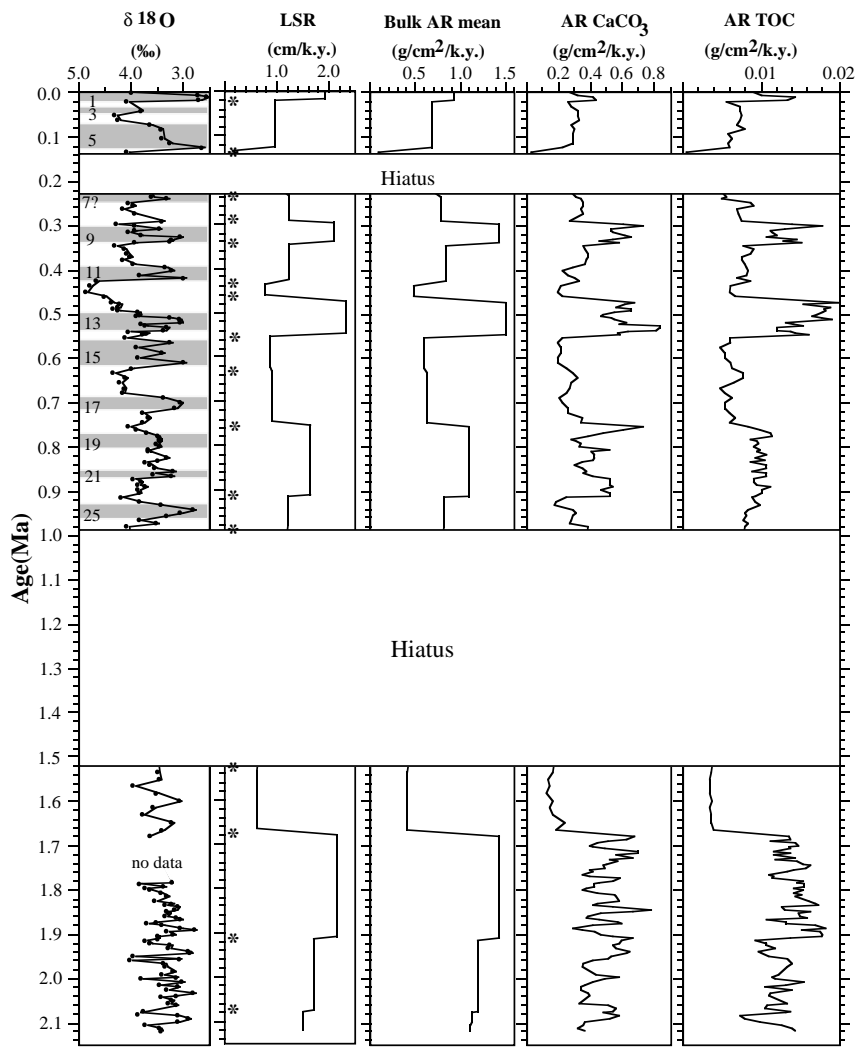

Figure 5. Linear sedimentation rates (LSR), bulk mass accumulation rates (bulk AR) and corresponding accumulation rates of bulk calcium carbonate and total organic carbon of Hole $959 \mathrm{C}$ vs. time. The stable oxygen isotope record (G.P. Lohmann, pers. comm., 1997), positions of interglacial stages (light-gray bars), and chronostratigraphic datums (asterisks: G.P. Lohmann, pers. comm., 1997; Shin et al., Chap. 39, this volume) used for flux calculations are shown for illustration.

veal characteristic maxima and minima known from other pelagic records of the Guinea Basin (Verardo and McIntyre, 1994; Bickert and Wefer, 1996). In the South Atlantic these patterns are commonly related to glacial/interglacial carbonate production/dissolution cycles caused by the vertical or lateral displacement of corrosive and noncorrosive bottom waters. Enhanced carbonate dissolution causes stronger fragmentation of carbonaceous shells and is recorded by reduced sand and carbonate contents. The sand and carbonate maxima and minima of Hole $959 \mathrm{C}$ are separated by $\sim 0.5$ to $1.4 \mathrm{~m}$, which correspond to $\sim 50$ to $140 \mathrm{k} . \mathrm{y}$., based on mean sedimentation rates of 1 $\mathrm{cm} / \mathrm{k}$.y. The sand fraction is almost exclusively composed of foraminifer tests that are partly filled by green clay and silt-sized quartz (Giresse et al., Chap. 43, this volume). Green grain concentrations comprise on average $\sim 10 \%$ of the total sand fraction, with the exception of the basal part of Core 159-959C-2H below 11 mbsf, where relative proportions rise up to $48 \%$ (Giresse et al., Chap. 43, this volume). Glacial/interglacial sand and carbonate cycles of Hole 959C younger than $\sim 0.9 \mathrm{Ma}$, equivalent to $11 \mathrm{mbsf}$, frequently show the highest sand and carbonate values co-occur with peak TOC contents during glacial intervals (Figs. 6, 7). This is most obviously recorded during isotopic Stages 22-24, 16, 12, 8, and 4. In this part of the core, sand and carbonate contents exhibit high-amplitude variations ranging from $15 \%$ to $50 \%$ and from $30 \%$ to $55 \%$, respectively. Correlation and relative amounts of sand and carbonate, however, distinctly change at the top and bottom of the record, suggesting general changes in the depositional setting prior to $\sim 1.5 \mathrm{Ma}$ and apparently for the last $60 \mathrm{ka}$.

The core section below 11 mbsf of Hole 959C ( 0.9 Ma and older) is characterized by lower but still highly variable carbonate contents, 


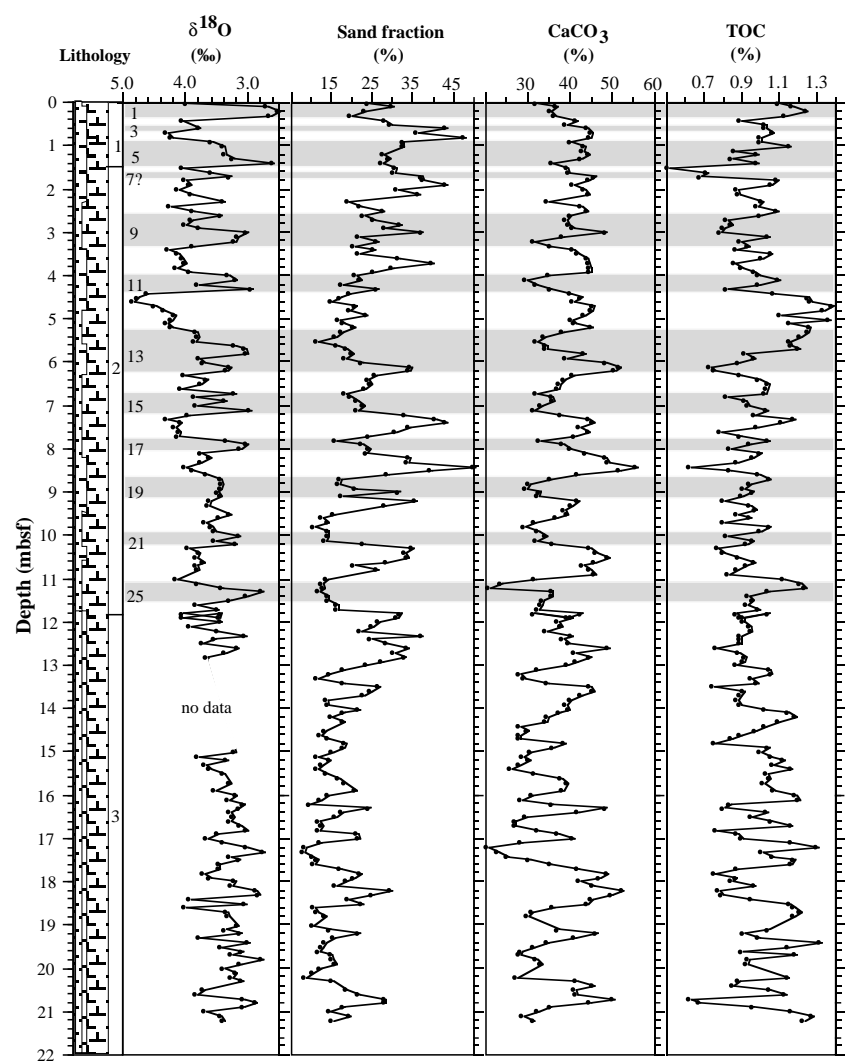

Figure 6 . Weight percentages of sand ( $>63-\mu \mathrm{m}$ fraction), bulk calcium carbonate, and total organic carbon vs. sub-bottom depth in the upper 22-m section of Hole 959C. Lithology (modified after Mascle, Lohmann, Clift, et al., 1996), stable oxygen isotope record (G.P. Lohmann, pers. comm., 1997), and position of interglacial stages (light-gray bars) are shown for illustration. Symbols used for graphic lithology are same as in Figure 4.

compared to shallower sections (Figs. 6, 7). Carbonate contents range from $20 \%$ to $50 \%$, whereas sand contents are reduced to values ranging from less than $10 \%$ to $35 \%$. Maxima in sand content are separated from $\sim 0.6$ to $1.4 \mathrm{~m}$, which correspond to $\sim 40$ to $90 \mathrm{k} . \mathrm{y}$., taking average mean linear sedimentation rates of $1.5 \mathrm{~cm} / \mathrm{k} . \mathrm{y}$. into account. TOC records are often anti-correlated to sand and carbonate records, revealing the typical pattern known from other areas of the South Atlantic Ocean (Verardo and McIntyre, 1994; Bickert and Wefer, 1996). Changes in frequency and amplitude in the sand and carbonate record of Hole 959C appear to be related to orbitally forced Milankovitch cycles, although the present time resolution of the records does not allow a final conclusion.

Above $0.8 \mathrm{mbsf}$ ( $60 \mathrm{ka}$ to the present), a single spike in the sand fraction occurs that is not accompanied by any change in carbonate content. Carbonate contents of this interval scatter at intermediate levels from $32 \%$ to $45 \%$. A clear correlation to the TOC signal is not evident. A continuous drop in bulk carbonate and overall reduced sand content in the uppermost $0.3 \mathrm{~m}$ of the sediment section is presumably related to the destruction of the core's top section.

\section{Pliocene-Pleistocene Variations in the Amount and Composition of Sedimentary Organic Carbon}

The corresponding Pliocene-Pleistocene TOC record of Hole 959C frequently exhibits no typical glacial/interglacial cyclicity but scatters at elevated levels from $0.5 \%$ to $1.4 \%$ (Figs. 6, 7; Table 3). This pattern is most obviously recorded in core sections above 11 mbsf (0.9 Ma and younger) where maxima in TOC are recorded dur-

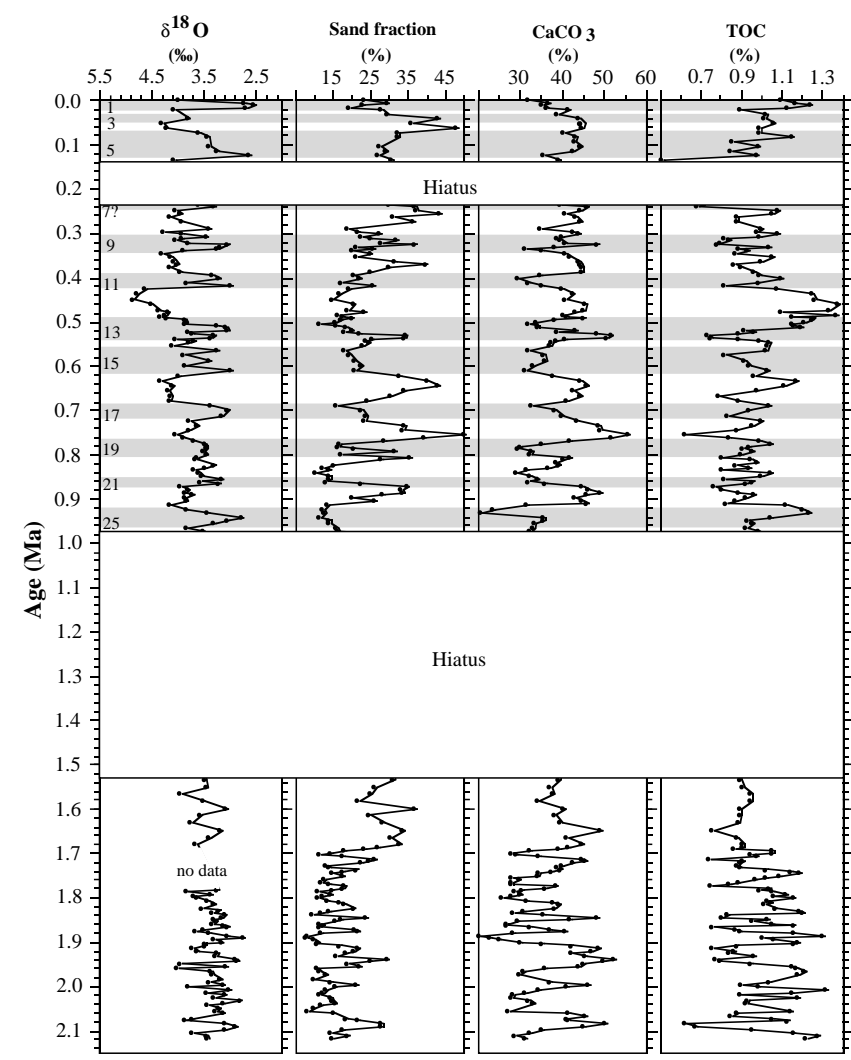

Figure 7. Weight percentages of sand ( $>63-\mu \mathrm{m}$ fraction), bulk calcium carbonate, and total organic carbon of Hole $959 \mathrm{C}$ vs. time. The stable oxygen isotope record (G.P. Lohmann, pers. comm., 1997) and position of interglacial stages (light-gray bars) are shown for illustration.

ing both glacial and interglacial intervals. In this section TOC maxima are often positively correlated to peaks in carbonate content (e.g., isotopic Stages 22-24, 16, 12, 8, and 4), whereas below 11 mbsf, TOC in general reveals an opposite trend in the carbonate record. Elevated TOC contents in glacial sections related to enhanced paleoproductivity are well documented in sediments all along the eastern Atlantic (Verardo and McIntyre, 1994; Bickert and Wefer, 1996). These patterns suggest a similar explanation for the TOC record of Hole 959C, although much more strongly influenced by terrigenous dilution and sediment redistribution according to the lower mean sedimentation rates. However, if continental dilution had a major effect on the depositional environment at Hole 959C, the formation of sand and carbonate cycles should have been affected in a similar way. It is therefore suggested that deposition of organic carbon off the Ivory Coast/Ghana was not exclusively controlled by changes in paleoproductivity but also was influenced by additional sedimentary or diagenetic processes.

To evaluate these additional factors it was necessary to determine the sources and relative amounts of sedimentary marine and terrigenous organic matter using a combined organic geochemical approach. Pliocene-Pleistocene profiles showing results from elemental (TOC, $\left.\mathrm{C}_{\text {org }} / \mathrm{N}_{\text {tot }}\right)$, pyrolytic (hydrogen index), isotopic $\left(\delta^{13} \mathrm{C}_{\text {org }}\right)$, and organic petrologic (marine organic matter and bulk detrinite $<10$ $\mu \mathrm{m}$ particle size) analysis are presented in Figure 8. Qualitative information on the composition of sedimentary organic matter is interpreted from hydrogen index and $\mathrm{C} / \mathrm{N}$ data, whereas the isotopic signal of sedimentary organic carbon and the microscopic results derived from maceral analysis are regarded as two independent sets of data that document quantitative amounts of marine and terrigenous organic matter. Variations in the immature thermal maturation level of sedimentary organic matter in Hole 959C, which would identify an ad- 
Table 3. Summary of sedimentological, elemental, pyrolytic, isotopic, and organic petrologic data for the upper $22 \mathrm{~m}$ of Hole $959 \mathrm{C}$.

\begin{tabular}{|c|c|c|c|c|c|c|c|c|}
\hline $\begin{array}{l}\text { Core, section, } \\
\text { interval }(\mathrm{cm})\end{array}$ & $\begin{array}{l}\text { Depth } \\
\text { (mbsf) }\end{array}$ & $\begin{array}{c}>63 \mu \mathrm{m} \\
(\%)\end{array}$ & $\begin{array}{c}\text { Inorg-C } \\
(\%)\end{array}$ & $\begin{array}{c}\mathrm{CaCO}_{3} \\
(\%)\end{array}$ & $\begin{array}{l}\text { Org-C } \\
(\%)\end{array}$ & $\begin{array}{c}\text { Tot-N } \\
(\%)\end{array}$ & $\begin{array}{l}\mathrm{T}_{\max } \\
\left({ }^{\circ} \mathrm{C}\right)\end{array}$ & $\begin{array}{c}\mathrm{S}_{1} \\
\text { (mg HC/g TOC) }\end{array}$ \\
\hline $1 \mathrm{H}-1,0-2.5$ & 0.01 & 24.1 & 5.00 & 32.46 & 1.11 & 0.13 & 363 & 0.003 \\
\hline $1 \mathrm{H}-1,10-12.5$ & 0.11 & 30.2 & 5.63 & 37.09 & 1.18 & & 378 & 0.130 \\
\hline $1 \mathrm{H}-1,20-22.5$ & 0.21 & 23.5 & 5.56 & 35.86 & 1.25 & 0.14 & 375 & 0.109 \\
\hline $1 \mathrm{H}-1,30-32.5$ & 0.31 & 20.0 & 5.56 & 36.77 & 1.14 & & 391 & 0.095 \\
\hline $1 \mathrm{H}-1,40-42.5$ & 0.41 & 28.4 & 5.93 & 41.93 & 0.90 & 0.10 & 379 & 0.069 \\
\hline $1 \mathrm{H}-1,50-52.5$ & 0.51 & 29.9 & 5.76 & 39.37 & 1.03 & 0.10 & 392 & 0.069 \\
\hline $1 \mathrm{H}-1,60-62.5$ & 0.61 & 43.5 & 6.38 & 44.55 & 1.03 & & 401 & 0.072 \\
\hline $1 \mathrm{H}-1,70-72.5$ & 0.71 & 36.4 & 6.54 & 45.52 & 1.07 & & 394 & 0.069 \\
\hline $1 \mathrm{H}-1,80-82.5$ & 0.81 & 48.2 & 6.43 & 45.22 & 1.00 & 0.10 & 389 & 0.000 \\
\hline $1 \mathrm{H}-1,90-92.5$ & 0.91 & 32.8 & 5.88 & 40.61 & 1.00 & & 384 & 0.088 \\
\hline $1 \mathrm{H}-1,100-102.5$ & 1.01 & 33.1 & 6.39 & 43.53 & 1.16 & 0.11 & 393 & 0.103 \\
\hline $1 \mathrm{H}-1,110-112.5$ & 1.11 & & 6.08 & 43.45 & 0.87 & & 391 & 0.056 \\
\hline $1 \mathrm{H}-1,120-122.5$ & 1.21 & 28.2 & 6.38 & 44.90 & 0.99 & 0.10 & 385 & 0.085 \\
\hline $1 \mathrm{H}-1,130-132.5$ & 1.31 & 29.5 & 6.02 & 43.05 & 0.85 & 0.09 & 386 & 0.050 \\
\hline $1 \mathrm{H}-1,140-142.5$ & 1.41 & 27.6 & 5.30 & 35.93 & 0.99 & 0.11 & 399 & 0.069 \\
\hline $1 \mathrm{H}-2,0-2.5$ & 1.51 & 31.3 & 5.30 & 39.85 & 0.52 & 0.07 & 390 & 0.098 \\
\hline $1 \mathrm{H}-2,12.5-15.0$ & 1.64 & 30.5 & 5.55 & 40.17 & 0.72 & 0.08 & 399 & 0.042 \\
\hline $1 \mathrm{H}-2,20-22.5$ & 1.71 & 37.4 & 6.25 & 46.33 & 0.69 & & 402 & 0.040 \\
\hline $1 \mathrm{H}-2,30-32.5$ & 1.81 & 37.7 & 6.47 & 44.77 & 1.09 & 0.10 & 399 & 0.061 \\
\hline $1 \mathrm{H}-2,40-42.5$ & 1.91 & 43.7 & 6.01 & 41.21 & 1.06 & & 389 & 0.053 \\
\hline $1 \mathrm{H}-2,50-52.5$ & 2.01 & 31.6 & 6.12 & 43.56 & 0.89 & 0.09 & 387 & 0.053 \\
\hline $1 \mathrm{H}-2,60-62.5$ & 2.11 & 36.9 & 6.26 & 44.70 & 0.89 & & 390 & 0.082 \\
\hline $2 \mathrm{H}-1,0-2.5$ & 2.31 & 19.5 & 5.23 & 35.17 & 1.01 & 0.11 & 396 & 0.119 \\
\hline $2 \mathrm{H}-1,10-12.5$ & 2.41 & 22.4 & 6.13 & 42.83 & 0.99 & & 400 & 0.058 \\
\hline $2 \mathrm{H}-1,20-22.5$ & 2.51 & 28.0 & 6.44 & 44.50 & 1.10 & 0.11 & 400 & 0.079 \\
\hline $2 \mathrm{H}-1,30-32.5$ & 2.61 & 23.1 & 5.85 & 40.35 & 1.01 & & 396 & 0.051 \\
\hline $2 \mathrm{H}-1,40-42.5$ & 2.71 & 25.6 & 5.55 & 39.27 & 0.83 & 0.08 & 394 & 0.034 \\
\hline $2 \mathrm{H}-1,50-52.5$ & 2.81 & 32.4 & 5.64 & 39.92 & 0.85 & & 400 & 0.039 \\
\hline $2 \mathrm{H}-1,60-62.5$ & 2.91 & 28.6 & 5.74 & 41.09 & 0.81 & & 393 & 0.031 \\
\hline $2 \mathrm{H}-1,70-72.5$ & 3.01 & 37.4 & 6.63 & 48.63 & 0.79 & 0.07 & 400 & 0.039 \\
\hline $2 \mathrm{H}-1,80-82.5$ & 3.11 & 22.0 & 5.67 & 38.47 & 1.05 & 0.09 & 399 & 0.051 \\
\hline $2 \mathrm{H}-1,90-92.5$ & 3.21 & 26.5 & 4.70 & 31.65 & 0.90 & & 389 & 0.056 \\
\hline $2 \mathrm{H}-1,100-102.5$ & 3.31 & 20.7 & 5.23 & 35.67 & 0.94 & & 396 & 0.051 \\
\hline $2 \mathrm{H}-1,110-112.5$ & 3.41 & 25.7 & 5.81 & 41.10 & 0.88 & 0.09 & 388 & 0.045 \\
\hline $2 \mathrm{H}-1,120-122.5$ & 3.51 & 22.0 & 6.11 & 42.06 & 1.06 & & 395 & 0.056 \\
\hline $2 \mathrm{H}-1,130-132.5$ & 3.61 & 31.9 & 6.35 & 44.49 & 1.01 & 0.08 & 397 & 0.048 \\
\hline $2 \mathrm{H}-1,140-142.5$ & 3.71 & 40.3 & 6.23 & 44.60 & 0.87 & & 389 & 0.034 \\
\hline $2 \mathrm{H}-2,0-2.5$ & 3.81 & 30.4 & 6.34 & 45.21 & 0.91 & & 387 & 0.059 \\
\hline $2 \mathrm{H}-2,10-12.5$ & 3.91 & 25.7 & 6.38 & 45.03 & 0.97 & 0.09 & 389 & 0.054 \\
\hline $2 \mathrm{H}-2,20-22.5$ & 4.01 & 21.3 & 5.26 & 35.44 & 1.00 & & 388 & 0.059 \\
\hline $2 \mathrm{H}-2,30-32.5$ & 4.11 & 22.5 & 4.70 & 29.94 & 1.11 & 0.11 & 389 & 0.056 \\
\hline $2 \mathrm{H}-2,40-42.5$ & 4.21 & 18.0 & 4.91 & 32.57 & 1.00 & & 395 & 0.062 \\
\hline $2 \mathrm{H}-2,50-52.5$ & 4.31 & 26.5 & 5.13 & 35.84 & 0.83 & 0.09 & 391 & 0.048 \\
\hline $2 \mathrm{H}-2,60-62.5$ & 4.41 & 19.7 & 5.96 & 40.58 & 1.08 & & 399 & 0.056 \\
\hline $2 \mathrm{H}-2,70-72.5$ & 4.51 & 17.4 & 6.44 & 43.12 & 1.26 & 0.11 & 408 & 0.073 \\
\hline $2 \mathrm{H}-2,80-82.5$ & 4.61 & 15.3 & 6.21 & 41.06 & 1.28 & & 409 & 0.070 \\
\hline $2 \mathrm{H}-2,90-92.5$ & 4.71 & 21.2 & 6.91 & 45.99 & 1.39 & 0.11 & 407 & 0.070 \\
\hline $2 \mathrm{H}-2,100-102.5$ & 4.81 & 19.6 & 6.81 & 45.57 & 1.34 & & 408 & 0.068 \\
\hline $2 \mathrm{H}-2,110-112.5$ & 4.91 & 23.9 & 6.37 & 43.83 & 1.11 & 0.10 & 401 & 0.056 \\
\hline $2 \mathrm{H}-2,120-122.5$ & 5.01 & 17.0 & 6.25 & 40.62 & 1.38 & 0.12 & 416 & 0.087 \\
\hline $2 \mathrm{H}-2,130-132.5$ & 5.11 & 18.2 & 6.15 & 41.58 & 1.16 & & 403 & 0.048 \\
\hline $2 \mathrm{H}-2,140-142.5$ & 5.21 & 20.8 & 6.71 & 45.32 & 1.27 & & 406 & 0.091 \\
\hline $2 \mathrm{H}-3,0-2.5$ & 5.31 & 17.8 & 5.87 & 38.44 & 1.26 & 0.11 & 400 & 0.212 \\
\hline $2 \mathrm{H}-3,10-12.5$ & 5.41 & 16.3 & 5.34 & 34.33 & 1.22 & & 402 & 0.069 \\
\hline $2 \mathrm{H}-3,20-22.5$ & 5.51 & 11.9 & 5.04 & 32.32 & 1.16 & 0.11 & 392 & 0.058 \\
\hline $2 \mathrm{H}-3,30-32.5$ & 5.61 & 16.8 & 5.34 & 34.73 & 1.17 & 0.11 & 399 & 0.066 \\
\hline $2 \mathrm{H}-3,40-42.5$ & 5.71 & 19.0 & 5.35 & 34.49 & 1.21 & & 402 & 0.069 \\
\hline $2 \mathrm{H}-3,50-52.5$ & 5.81 & 20.5 & 6.18 & 43.75 & 0.93 & & 398 & 0.049 \\
\hline $2 \mathrm{H}-3,60-62.5$ & 5.91 & 18.7 & 5.69 & 39.29 & 0.97 & & 390 & 0.044 \\
\hline $2 \mathrm{H}-3,70-72.5$ & 6.01 & 22.6 & 6.74 & 48.66 & 0.90 & & 390 & 0.063 \\
\hline $2 \mathrm{H}-3,80-82.5$ & 6.11 & 35.0 & 6.97 & 51.84 & 0.74 & 0.08 & 393 & 0.041 \\
\hline $2 \mathrm{H}-3,90-92.5$ & 6.21 & 34.3 & 6.86 & 50.82 & 0.76 & & & \\
\hline $2 \mathrm{H}-3,100-102.5$ & 6.31 & 26.1 & 5.85 & 41.25 & 0.90 & 0.09 & 389 & 0.047 \\
\hline $2 \mathrm{H}-3,110-112.5$ & 6.41 & 24.3 & 5.67 & 38.86 & 1.00 & & 389 & 0.052 \\
\hline $2 \mathrm{H}-3,120-122.5$ & 6.51 & 25.2 & 5.61 & 38.04 & 1.05 & 0.10 & 391 & 0.049 \\
\hline $2 \mathrm{H}-3,130-132.5$ & 6.61 & 23.4 & 5.55 & 37.59 & 1.04 & & 391 & 0.052 \\
\hline $2 \mathrm{H}-3,140-142.5$ & 6.71 & 18.4 & 4.94 & 32.55 & 1.03 & 0.10 & 390 & 0.052 \\
\hline $2 \mathrm{H}-4,0-2.5$ & 6.81 & 20.0 & 5.14 & 35.92 & 0.82 & & 386 & 0.058 \\
\hline $2 \mathrm{H}-4,10-2.5$ & 6.91 & 21.7 & 5.30 & 36.47 & 0.92 & 0.10 & 388 & 0.041 \\
\hline $2 \mathrm{H}-4,20-22.5$ & 7.01 & 23.0 & 4.98 & 33.59 & 0.95 & & 390 & 0.036 \\
\hline $2 \mathrm{H}-4,30-32.5$ & 7.11 & 21.6 & 4.84 & 31.68 & 1.04 & 0.11 & 386 & 0.058 \\
\hline $2 \mathrm{H}-4,40-42.5$ & 7.21 & 33.3 & 5.57 & 38.30 & 0.97 & & 388 & 0.055 \\
\hline $2 \mathrm{H}-4,50-52.5$ & 7.31 & 40.8 & 6.57 & 44.86 & 1.18 & 0.11 & 407 & 0.052 \\
\hline $2 \mathrm{H}-6,60-62.5$ & 7.41 & 43.6 & 6.65 & 46.02 & 1.12 & & 404 & 0.049 \\
\hline $2 \mathrm{H}-4,70-72.5$ & 7.51 & 34.5 & 6.12 & 42.77 & 0.99 & 0.08 & 402 & 0.025 \\
\hline $2 \mathrm{H}-4,80-82.5$ & 7.61 & 31.0 & 6.16 & 44.62 & 0.80 & & 392 & 0.016 \\
\hline $2 \mathrm{H}-4,90-92.5$ & 7.71 & 24.7 & 5.86 & 41.36 & 0.90 & & 388 & 0.021 \\
\hline $2 \mathrm{H}-4,100-102.5$ & 7.81 & 16.5 & 5.04 & 33.30 & 1.05 & 0.09 & 391 & 0.030 \\
\hline $2 \mathrm{H}-4,110-112.5$ & 7.91 & 22.9 & 5.59 & 38.64 & 0.95 & & 390 & 0.039 \\
\hline $2 \mathrm{H}-4,120-22.5$ & 8.01 & 24.5 & 5.70 & 40.44 & 0.84 & 0.08 & 390 & 0.022 \\
\hline $2 \mathrm{H}-4,130-132.5$ & 8.11 & 23.7 & 6.30 & 44.09 & 1.01 & 0.09 & 398 & 0.039 \\
\hline $2 \mathrm{H}-4,140-142.5$ & 8.21 & 34.5 & 6.84 & 48.92 & 0.96 & & 397 & 0.026 \\
\hline $2 \mathrm{H}-5,0-2.5$ & 8.31 & 34.2 & 6.82 & 49.42 & 0.89 & 0.08 & 401 & 0.010 \\
\hline $2 \mathrm{H}-5,10-12.5$ & 8.41 & 50.3 & 7.35 & 55.96 & 0.63 & 0.06 & 399 & 0.025 \\
\hline $2 \mathrm{H}-5,20-22.5$ & 8.51 & 39.6 & 7.09 & 52.03 & 0.85 & & 406 & 0.039 \\
\hline $2 \mathrm{H}-5,30-32.5$ & 8.61 & 29.1 & 6.09 & 42.37 & 1.00 & & 402 & 0.039 \\
\hline $2 \mathrm{H}-5,40-42.5$ & 8.71 & 17.3 & 5.33 & 35.60 & 1.06 & 0.10 & 397 & 0.039 \\
\hline $2 \mathrm{H}-5,50-52.5$ & 8.81 & 17.0 & 4.64 & 30.78 & 0.95 & 0.09 & 386 & 0.039 \\
\hline $2 \mathrm{H}-5,60-62.5$ & 8.91 & 21.1 & 4.50 & 37.47 & 0.92 & 0.10 & 390 & 0.035 \\
\hline
\end{tabular}


Table 3 (continued).

\begin{tabular}{|c|c|c|c|c|c|c|c|c|}
\hline $\begin{array}{l}\text { Core, section, } \\
\text { interval }(\mathrm{cm})\end{array}$ & $\begin{array}{l}\text { Depth } \\
\text { (mbsf) }\end{array}$ & $\begin{array}{c}>63 \mu \mathrm{m} \\
(\%)\end{array}$ & $\begin{array}{c}\text { Inorg-C } \\
(\%)\end{array}$ & $\begin{array}{c}\mathrm{CaCO}_{3} \\
(\%)\end{array}$ & $\begin{array}{c}\text { Org-C } \\
(\%)\end{array}$ & $\begin{array}{c}\text { Tot-N } \\
(\%)\end{array}$ & $\begin{array}{l}\mathrm{T}_{\max } \\
\left({ }^{\circ} \mathrm{C}\right)\end{array}$ & $\begin{array}{c}\mathrm{S}_{1} \\
\text { (mg HC/g TOC) }\end{array}$ \\
\hline $2 \mathrm{H}-5,70-72.5$ & 9.01 & 32.0 & 4.96 & 33.33 & 0.96 & & 393 & 0.028 \\
\hline $2 \mathrm{H}-5,80-82.5$ & 9.11 & 17.7 & 4.87 & 32.97 & 0.91 & & 390 & 0.035 \\
\hline $2 \mathrm{H}-5,90-92.5$ & 9.21 & 36.1 & 5.86 & 42.11 & 0.81 & 0.08 & 388 & 0.025 \\
\hline $2 \mathrm{H}-5,100-102.5$ & 9.31 & 28.3 & 5.86 & 40.90 & 0.95 & & 399 & 0.032 \\
\hline $2 \mathrm{H}-5,110-112.5$ & 9.41 & 20.0 & 5.67 & 38.99 & 0.99 & 0.09 & 397 & 0.028 \\
\hline $2 \mathrm{H}-5,120-122.5$ & 9.51 & 16.0 & 5.66 & 39.82 & 0.88 & & 396 & 0.032 \\
\hline $2 \mathrm{H}-5,130-132.5$ & 9.61 & 13.0 & 5.42 & 37.22 & 0.95 & & 389 & 0.028 \\
\hline $2 \mathrm{H}-5,140-142.5$ & 9.71 & 14.4 & 4.68 & 32.21 & 0.81 & 0.08 & 391 & 0.028 \\
\hline $2 \mathrm{H}-6,0-2.5$ & 9.81 & $\begin{array}{l}11.4 \\
11.0\end{array}$ & $\begin{array}{l}4.00 \\
4.61\end{array}$ & 29.62 & $\begin{array}{l}.01 \\
1.06\end{array}$ & 0.08 & 404 & 0.053 \\
\hline $2 \mathrm{H}-6,10-12.5$ & 9.91 & 14.4 & 4.95 & 32.80 & 1.01 & & 393 & 0.032 \\
\hline $2 \mathrm{H}-6,20-22.5$ & 10.01 & 14.5 & 5.00 & 34.75 & 0.83 & 0.08 & 397 & 0.010 \\
\hline $2 \mathrm{H}-6,30-32.5$ & 10.11 & 13.6 & 4.87 & 32.50 & 0.96 & 0.09 & 389 & 0.061 \\
\hline $2 \mathrm{H}-6,40-42.5$ & 10.21 & 3.0 & 5.31 & 36.47 & 0.94 & 0.07 & 399 & 0.058 \\
\hline $2 \mathrm{H}-6,50-52.5$ & 10.31 & 35.3 & 6.20 & 45.19 & 0.78 & & 399 & 0.041 \\
\hline $2 \mathrm{H}-6,60-62.5$ & 10.41 & 33.5 & 6.42 & $\begin{array}{l}46.72 \\
46.72\end{array}$ & 0.81 & 0.09 & 397 & 0.044 \\
\hline $2 \mathrm{H}-6,70-72.5$ & 10.51 & 34.0 & 6.82 & 49.35 & 0.89 & & 403 & 0.041 \\
\hline $2 \mathrm{H}-6,80-82.5$ & 10.61 & 29.0 & 6.54 & 46.34 & 0.97 & 0.07 & 394 & 0.052 \\
\hline $2 \mathrm{H}-6,90-92.5$ & 10.71 & 20.8 & 6.14 & 43.41 & 0.93 & & 396 & 0.052 \\
\hline $2 \mathrm{H}-6,100-102.5$ & 10.81 & 26.7 & 6.30 & 45.14 & 0.88 & 0.07 & 406 & 0.064 \\
\hline $2 \mathrm{H}-6,110-112.5$ & 10.91 & & 6.39 & 46.28 & 0.83 & & 390 & 0.055 \\
\hline $2 \mathrm{H}-6,120-122.5$ & 11.01 & 14.0 & 4.97 & 31.95 & 1.13 & 0.09 & 400 & 0.070 \\
\hline $2 \mathrm{H}-6,130-132.5$ & 11.11 & 13.0 & 4.13 & 24.26 & 1.22 & & 401 & 0.055 \\
\hline $2 \mathrm{H}-6,140-142.5$ & 11.21 & 13.1 & 3.80 & 21.26 & 1.24 & 0.10 & 399 & 0.087 \\
\hline $2 \mathrm{H}-7,0-2.5$ & 11.31 & 12.1 & 5.39 & 36.11 & 1.05 & & 398 & 0.070 \\
\hline $2 \mathrm{H}-7,10-12.5$ & 11.41 & 14.4 & 5.28 & 36.20 & 0.94 & & 402 & 0.050 \\
\hline $2 \mathrm{H}-7,20-22.5$ & 11.51 & 14.5 & 5.04 & 33.98 & 0.96 & 0.08 & 403 & 0.047 \\
\hline $2 \mathrm{H}-7,30-32.5$ & 11.61 & 16.6 & 4.96 & 33.52 & 0.94 & 0.00 & 397 & 0.050 \\
\hline $2 \mathrm{H}-7,40-42.5$ & 11.71 & 16.9 & 4.93 & 32.76 & 1.00 & 0.09 & 399 & 0.058 \\
\hline $2 \mathrm{H}-7,50-52.5$ & 11.81 & 32.2 & 6.04 & 43.01 & 0.88 & & 399 & 0.047 \\
\hline $2 \mathrm{H}-7,60-62.5$ & 11.91 & 31.6 & 5.68 & 39.81 & 0.90 & 0.08 & 397 & 0.052 \\
\hline $3 \mathrm{H}-1,0-2.5$ & 11.81 & & 4.85 & 31.67 & 1.05 & & & \\
\hline $3 \mathrm{H}-1,10-12.5$ & 11.91 & & 5.80 & 40.69 & 0.92 & & & \\
\hline $3 \mathrm{H}-1,20-22.5$ & 12.01 & 26.8 & 5.43 & 37.57 & 0.92 & 0.09 & 394 & 0.052 \\
\hline $3 \mathrm{H}-1,30-32.5$ & 12.11 & 25.4 & 5.55 & 38.31 & 0.95 & & 398 & 0.052 \\
\hline $3 \mathrm{H}-1,40-42.5$ & 12.21 & 22.3 & 5.13 & 34.71 & 0.96 & & 395 & 0.047 \\
\hline $3 \mathrm{H}-1,50-52.5$ & 12.31 & 37.5 & 5.78 & 40.62 & 0.90 & 0.08 & 390 & 0.050 \\
\hline $3 \mathrm{H}-1,60-62.5$ & 12.41 & 25.0 & 5.55 & 38.72 & 0.90 & & 393 & 0.044 \\
\hline $3 \mathrm{H}-1,70-72.5$ & 12.51 & 28.7 & 5.71 & 40.06 & 0.90 & 0.08 & 394 & 0.052 \\
\hline $3 \mathrm{H}-1,80-82.5$ & 12.61 & 34.0 & 6.69 & 49.33 & 0.77 & $\begin{array}{l}0.00 \\
0.00\end{array}$ & 389 & 0.044 \\
\hline $3 \mathrm{H}-1,90-92.5$ & 12.71 & 30.8 & 5.86 & 41.42 & 0.89 & 0.08 & 394 & 0.044 \\
\hline $3 \mathrm{H}-1,100-102.5$ & 12.81 & 33.4 & 6.35 & 45.19 & 0.92 & & 388 & 0.050 \\
\hline $3 \mathrm{H}-1,110-112.5$ & 12.91 & 27.6 & 5.95 & 41.95 & 0.92 & & 406 & 0.040 \\
\hline $3 \mathrm{H}-1,120-122.5$ & 13.01 & 23.8 & 5.65 & 39.78 & 0.87 & 0.08 & 393 & 0.032 \\
\hline $3 \mathrm{H}-1,130-132.5$ & 13.11 & 18.4 & 4.99 & 32.74 & 1.06 & & 394 & 0.057 \\
\hline $3 \mathrm{H}-1,140-142.5$ & 13.21 & $\begin{array}{l}14.4^{4} \\
14.9\end{array}$ & 4.47 & 28.34 & 1.06 & & 391 & 0.064 \\
\hline $3 \mathrm{H}-2,0-2.5$ & 13.31 & 12.0 & 4.50 & 29.53 & 0.96 & & 397 & 0.055 \\
\hline $3 \mathrm{H}-2,10-12.5$ & 13.41 & 18.3 & 5.20 & 35.09 & 0.99 & & 391 & 0.060 \\
\hline $3 \mathrm{H}-2,20-22.5$ & 13.51 & 26.9 & 6.16 & 45.00 & 0.75 & & 391 & 0.045 \\
\hline $3 \mathrm{H}-2,30-32.5$ & 13.61 & 25.1 & 6.44 & 45.99 & 0.92 & 0.05 & 400 & 0.055 \\
\hline $3 \mathrm{H}-2,40-42.5$ & 13.71 & 23.2 & 6.07 & 43.05 & 0.90 & 0.00 & 399 & 0.037 \\
\hline $3 \mathrm{H}-2,50-52.5$ & 13.81 & 13.9 & 5.75 & 40.55 & 0.89 & 0.07 & 399 & 0.032 \\
\hline $3 \mathrm{H}-2,60-62.5$ & 13.91 & 14.5 & 5.61 & 39.21 & 0.90 & & 400 & 0.040 \\
\hline $3 \mathrm{H}-2,70-72.5$ & 14.01 & 21.9 & 5.85 & 40.15 & 1.03 & & 398 & 0.050 \\
\hline $3 \mathrm{H}-2,80-82.5$ & 14.11 & 18.3 & 5.72 & 38.00 & 1.15 & 0.10 & 406 & 0.067 \\
\hline $3 \mathrm{H}-2,90-92.5$ & 14.21 & 15.4 & 5.40 & 35.00 & 1.20 & & 403 & 0.040 \\
\hline $3 \mathrm{H}-2,100-102.5$ & 14.31 & 18.4 & 5.24 & 34.49 & 1.10 & 0.09 & 401 & 0.050 \\
\hline $3 \mathrm{H}-2,110-112.5$ & 14.41 & 10.4 & 4.45 & 28.50 & 1.03 & 0.10 & 397 & 0.045 \\
\hline $3 \mathrm{H}-2,120-122.5$ & 14.51 & 13.5 & 4.63 & 30.40 & 0.98 & & 396 & 0.055 \\
\hline $3 \mathrm{H}-2,130-132.5$ & 14.61 & 12.7 & 4.30 & 28.33 & 0.90 & 0.08 & 397 & 0.042 \\
\hline $3 \mathrm{H}-2,140-142.5$ & 14.71 & 14.4 & 4.29 & 28.63 & 0.85 & & 387 & 0.047 \\
\hline $3 \mathrm{H}-3,0-2.5$ & 14.81 & 18.6 & 5.43 & 38.91 & 0.76 & 0.06 & & \\
\hline $3 \mathrm{H}-3,10-12.5$ & 14.91 & 18.3 & 5.42 & 36.41 & 1.05 & & 399 & 0.050 \\
\hline $3 \mathrm{H}-3,20-22.5$ & 15.01 & 15.4 & 4.72 & 30.93 & 1.01 & 0.09 & 395 & 0.045 \\
\hline $3 \mathrm{H}-3,30-32.5$ & 15.11 & 11.7 & 4.55 & 29.05 & 1.06 & & 396 & 0.050 \\
\hline $3 \mathrm{H}-3,40-42.5$ & 15.21 & 14.9 & 4.80 & 30.59 & 1.13 & 0.09 & 395 & 0.047 \\
\hline $3 \mathrm{H}-3,50-52.5$ & 15.31 & 13.1 & 4.50 & 28.56 & 1.07 & & 398 & 0.050 \\
\hline $3 \mathrm{H}-3,60-62.5$ & 15.41 & 11.8 & 4.34 & 26.37 & 1.17 & & 391 & 0.052 \\
\hline $3 \mathrm{H}-3,70-72.5$ & 15.51 & 14.0 & 4.89 & 32.06 & 1.04 & & 392 & 0.064 \\
\hline $3 \mathrm{H}-3,80-82.5$ & 15.61 & $\begin{array}{l}17.0 \\
17.2\end{array}$ & $\begin{array}{l}.0 \% 9 \\
5.64\end{array}$ & 38.19 & $\begin{array}{l}1.04 \\
1.05\end{array}$ & & 395 & 0.055 \\
\hline $3 \mathrm{H}-3,90-92.5$ & 15.71 & 18.5 & 5.79 & 39.71 & 1.02 & 0.09 & 399 & 0.050 \\
\hline $3 \mathrm{H}-3,110-112.5$ & 15.91 & 21.1 & 5.71 & 38.60 & 1.08 & & & \\
\hline $3 \mathrm{H}-3,120-122.5$ & 16.01 & 14.5 & 4.97 & 31.47 & 1.20 & & 401 & 0.069 \\
\hline $3 \mathrm{H}-3,130-132.5$ & 16.11 & 12.4 & 4.68 & 28.86 & 1.21 & 0.11 & 408 & 0.072 \\
\hline $3 \mathrm{H}-3,140-142.5$ & 16.21 & 10.1 & 5.20 & 36.23 & 0.85 & & 381 & 0.059 \\
\hline $3 \mathrm{H}-4,0-2.5$ & 16.31 & 24.5 & 6.68 & 48.90 & 0.81 & & 393 & 0.062 \\
\hline $3 \mathrm{H}-4,10-12.5$ & 16.41 & 17.8 & 6.10 & 42.18 & 1.04 & & 397 & 0.068 \\
\hline $3 \mathrm{H}-4,20-22.5$ & 16.51 & 16.3 & 4.57 & 30.03 & 0.96 & 0.10 & 396 & 0.050 \\
\hline $3 \mathrm{H}-4,30-32.5$ & 16.61 & 12.0 & 4.34 & 27.29 & 1.06 & 0.10 & 393 & 0.088 \\
\hline $3 \mathrm{H}-4,40-42.5$ & 16.71 & 13.1 & 4.47 & 27.49 & 1.17 & & 392 & 0.091 \\
\hline $3 \mathrm{H}-4,50-52.5$ & 16.81 & 12.3 & 4.70 & 39.18 & 0.77 & 0.08 & 390 & 0.048 \\
\hline $3 \mathrm{H}-4,60-62.5$ & 16.91 & 21.7 & 5.41 & 37.66 & 0.88 & & 383 & 0.048 \\
\hline $3 \mathrm{H}-4,70-72.5$ & 17.01 & 22.1 & 5.85 & 41.17 & 0.91 & 0.08 & 396 & 0.048 \\
\hline $3 \mathrm{H}-4,80-82.5$ & 17.11 & 12.7 & 4. & 28. & 1.1 & & 39 & \\
\hline $3 \mathrm{H}-4,90-92.5$ & 17.21 & 8.9 & 3.83 & 20.97 & 1.31 & 0.08 & 393 & 0.091 \\
\hline $3 \mathrm{H}-4,100-102.5$ & 17.31 & 8.6 & 3.82 & 23.37 & 1.02 & & 390 & 0.074 \\
\hline $3 \mathrm{H}-4,110-112.5$ & 17.41 & 10.5 & 4.16 & 25.75 & 1.07 & 0.10 & 392 & 0.065 \\
\hline $3 \mathrm{H}-4,120-122.5$ & 17.51 & 11.7 & 4.87 & 30.65 & 1.19 & 0.10 & 404 & 0.076 \\
\hline $3 \mathrm{H}-4,130-132.5$ & 17.61 & 11.2 & 5.44 & 35.57 & 1.17 & & 407 & 0.074 \\
\hline $3 \mathrm{H}-4,140-142.5$ & 17.71 & 17.6 & 5.98 & 42.41 & 0.89 & 0.08 & 394 & 0.059 \\
\hline
\end{tabular}


Table 3 (continued).

\begin{tabular}{|c|c|c|c|c|c|c|c|c|c|c|c|}
\hline $\begin{array}{l}\text { Core, section, } \\
\text { interval }(\mathrm{cm})\end{array}$ & $\begin{array}{l}\text { Depth } \\
\text { (mbsf) }\end{array}$ & $\begin{array}{c}>63 \mu \mathrm{m} \\
(\%)\end{array}$ & $\begin{array}{c}\text { Inorg-C } \\
(\%)\end{array}$ & $\begin{array}{c}\mathrm{CaCO}_{3} \\
(\%)\end{array}$ & $\begin{array}{l}\text { Org-C } \\
(\%)\end{array}$ & $\begin{array}{c}\text { Tot-N } \\
(\%)\end{array}$ & $\begin{array}{l}\mathrm{T}_{\max } \\
\left({ }^{\circ} \mathrm{C}\right)\end{array}$ & $\begin{array}{c}\mathrm{S}_{1} \\
\text { (mg HC/g TOC) }\end{array}$ & $\begin{array}{c}\mathrm{S}_{2} \\
\text { (mg HC/g TOC) }\end{array}$ & $\begin{array}{l}\delta^{13} \mathrm{C}_{\text {org }} \\
(\% \circ \mathrm{PDB})\end{array}$ & $\begin{array}{c}\text { MOM } \\
(\%)\end{array}$ \\
\hline $3 \mathrm{H}-5,0-2.5$ & 17.81 & 22.4 & 6.67 & 49.16 & 0.77 & & & & & & \\
\hline $3 \mathrm{H}-5,10-12.5$ & 17.91 & 20.9 & 6.53 & 47.12 & 0.88 & & 409 & 0.034 & 0.664 & & \\
\hline $3 \mathrm{H}-5,20-22.5$ & 18.01 & 19.2 & 5.96 & 42.55 & 0.85 & 0.08 & 400 & 0.048 & 0.624 & -19.09 & \\
\hline $3 \mathrm{H}-5,30-32.5$ & 18.11 & 16.5 & 6.48 & 45.91 & 0.97 & 0.09 & 413 & 0.051 & 0.793 & -19.11 & \\
\hline $3 \mathrm{H}-5,40-42.5$ & 18.21 & 29.8 & 7.10 & 52.64 & 0.78 & & 402 & 0.045 & 0.615 & & \\
\hline $3 \mathrm{H}-5,50-52.5$ & 18.31 & 25.6 & 6.84 & 50.28 & 0.81 & 0.07 & 394 & 0.037 & 0.506 & -19.04 & \\
\hline $3 \mathrm{H}-5,60-62.5$ & 18.41 & 19.2 & 6.40 & 45.34 & 0.96 & & 401 & 0.048 & 0.605 & & \\
\hline $3 \mathrm{H}-5,70-72.5$ & 18.51 & 22.8 & 6.48 & 44.32 & 1.16 & 0.09 & 413 & 0.062 & 0.833 & -18.36 & \\
\hline $3 \mathrm{H}-5,80-82.5$ & 18.61 & 11.2 & 5.57 & 36.51 & 1.18 & & 416 & 0.048 & 0.783 & & \\
\hline $3 \mathrm{H}-5,90-92.5$ & 18.71 & 11.9 & 4.99 & 31.40 & 1.22 & 0.11 & 406 & 0.059 & 0.872 & -18.38 & 46.1 \\
\hline $3 \mathrm{H}-5,100-102.5$ & 18.81 & 13.6 & 4.83 & 30.30 & 1.19 & & 411 & 0.051 & 0.704 & & \\
\hline $3 \mathrm{H}-5,120-122.5$ & 19.01 & 10.6 & & & & & & & & & \\
\hline $3 \mathrm{H}-5,130-132.5$ & 19.11 & 15.0 & 5.56 & 37.61 & 1.05 & 0.09 & 396 & 0.054 & 0.743 & -19.35 & 46.8 \\
\hline $3 \mathrm{H}-5,140-142.5$ & 19.21 & 21.9 & 6.51 & 46.64 & 0.91 & 0.09 & 392 & 0.045 & 0.535 & -18.98 & 41.2 \\
\hline $3 \mathrm{H}-6,0-2.5$ & 19.31 & 16.1 & 5.98 & 41.49 & 1.00 & & 397 & 0.099 & 0.684 & -19.44 & 39.7 \\
\hline $3 \mathrm{H}-6,10-12.5$ & 19.41 & 13.8 & 5.54 & 35.08 & 1.33 & 0.11 & 413 & 0.085 & 1.130 & -18.94 & \\
\hline $3 \mathrm{H}-6,20-22.5$ & 19.51 & 13.0 & 4.99 & 31.90 & 1.16 & 0.11 & 409 & 0.071 & 0.862 & -18.58 & 34.0 \\
\hline $3 \mathrm{H}-6,30-32.5$ & 19.61 & 12.2 & 4.36 & 28.73 & 0.91 & 0.09 & 385 & 0.045 & 0.446 & -18.60 & \\
\hline $3 \mathrm{H}-6,40-42.5$ & 19.71 & 15.1 & 4.61 & 28.48 & 1.19 & 0.10 & 395 & 0.068 & 0.793 & -18.78 & \\
\hline $3 \mathrm{H}-6,50-52.5$ & 19.81 & 15.4 & 4.82 & 32.29 & 0.94 & & 399 & 0.051 & 0.595 & & \\
\hline $3 \mathrm{H}-6,60-62.5$ & 19.91 & 16.4 & 4.97 & 33.60 & 0.93 & 0.08 & 390 & 0.047 & 0.539 & -18.62 & \\
\hline $3 \mathrm{H}-6,70-72.5$ & 20.01 & 12.6 & & & & & & & & & \\
\hline $3 \mathrm{H}-6,80-82.5$ & 20.11 & 10.5 & & & & & & & & & \\
\hline $3 \mathrm{H}-6,90-92.5$ & 20.21 & 8.8 & 4.48 & 27.71 & 1.16 & 0.11 & 401 & 0.044 & 0.755 & -18.93 & 52.3 \\
\hline $3 \mathrm{H}-6,100-102.5$ & 20.31 & 15.7 & 5.92 & 41.90 & 0.89 & & 391 & 0.024 & 0.461 & & \\
\hline $3 \mathrm{H}-6,110-112.5$ & 20.41 & & 6.35 & 45.75 & 0.86 & 0.08 & 397 & 0.028 & 0.461 & -19.04 & \\
\hline $3 \mathrm{H}-6,120-122.5$ & 20.51 & 19.0 & 6.03 & 41.38 & 1.06 & & 411 & 0.032 & 0.745 & & \\
\hline $3 \mathrm{H}-6,130-132.5$ & 20.61 & 22.2 & 6.16 & 41.85 & 1.14 & 0.10 & 403 & 0.030 & 0.745 & -18.69 & \\
\hline $3 \mathrm{H}-6,140-142.5$ & 20.71 & 28.5 & 6.71 & 50.58 & 0.63 & & 392 & 0.014 & 0.334 & & \\
\hline $3 \mathrm{H}-7,0-2.5$ & 20.81 & 28.6 & 6.12 & 45.31 & 0.68 & 0.08 & 394 & 0.024 & 0.383 & -18.53 & \\
\hline $3 \mathrm{H}-7,10-12.5$ & 20.91 & 18.4 & 5.27 & 35.82 & 0.97 & & 392 & 0.028 & 0.471 & & \\
\hline $3 \mathrm{H}-7,20-22.5$ & 21.01 & 15.0 & 5.09 & 32.70 & 1.17 & 0.11 & 403 & 0.032 & 0.677 & -18.22 & 39.1 \\
\hline $3 \mathrm{H}-7,30-32.5$ & 21.11 & 19.6 & 4.81 & 29.35 & 1.29 & & 406 & 0.036 & 0.824 & & \\
\hline $3 \mathrm{H}-7,40-42.5$ & 21.21 & 15.4 & 5.02 & 31.57 & 1.23 & 0.12 & 409 & 0.042 & 0.942 & -18.68 & 54.1 \\
\hline
\end{tabular}

Note: Sedimentological $=$ sand fraction $>63 \mu \mathrm{m}$; elemental $=$ Inorg- $\mathrm{C}, \mathrm{CaCO}_{3}$, Org-C, and Tot-N; pyrolytic $=\mathrm{T}_{\max }, \mathrm{S}_{1}(\mathrm{mg} \mathrm{HC} / \mathrm{g} \mathrm{TOC}), \mathrm{S}_{2}(\mathrm{mg} \mathrm{HC} / \mathrm{g} \mathrm{TOC})$, isotopic $=\delta^{13} \mathrm{C}_{\text {org }}$ $(\% \mathrm{PDB})$; and organic petrologic $=$ marine organic matter $(\mathrm{MOM}[\%])$.

mixture of reworked, thermally mature organic matter from adjacent submarine outcrops of older strata, were not encountered, based on $\mathrm{T}_{\max }$ records obtained from Rock-Eval analysis (Fig. 9). In terms of kerogen-type Hydrogen Index data noncorrected for mineral-matrix effects consistently plot in the immature field of kerogen type IV, suggesting that inert sedimentary organic material is dominant in Hole 959C samples. A higher variability covering the fields of kerogen types VI to II (inert to mixed marine/terrigenous), however, is indicated if Rock-Eval data are corrected for mineral-matrix effects (Fig. 9).

Hydrogen indices corrected for mineral matrix effects range from $70 \mathrm{mg} \mathrm{HC} / \mathrm{g}$ TOC to $170 \mathrm{mg} \mathrm{HC} / \mathrm{g}$ TOC, suggesting a general dominance of hydrogen-depleted organic matter with some periodic admixture of hydrogen-enriched (marine) organic matter (Fig. 8). Minor fluctuations in the relative proportion of more hydrogen-enriched organic matter are indicated by increased hydrogen indices prior to 1.84 Ma, and at the end of isotopic Stages 22, 19, 13, 9, and 5. Corresponding contents and $\mathrm{AR}$ of TOC in these intervals are frequently elevated, which presumably indicates favorable conditions for the preservation of marine-derived organic matter.

$\mathrm{C} / \mathrm{N}$ ratios on average scatter around values exceeding 10 . They rarely reach values higher than 15 . Interpretation of $\mathrm{C} / \mathrm{N}$ values with regard to marine vs. terrigenous organic carbon is considered problematic (Müller, 1977; Stein, 1991, Verardo and McIntyre, 1994). Elevated proportions of nitrogen-rich, marine organic matter cannot be identified by the $\mathrm{C} / \mathrm{N}$ record. However, the two peaks in $\mathrm{C} / \mathrm{N}$ at 1.88 Ma and 1.72 Ma may suggest higher proportions of nitrogen-poor organic matter (Fig. 8).

Comparison of the isotopic carbon record derived from sedimentary organic carbon $\left(\delta^{13} \mathrm{C}_{\mathrm{org}}\right)$ and results obtained from maceral analysis reveal striking differences concerning the quantitative amounts of marine and terrigenous organic carbon (Figs. 8, 10). The discrepancy between both records, however, seems not to be entirely explained by analytical limitations of either method requiring an alternative explanation.
Based on microscopic results, quantitative proportions of marine organic matter range from $30 \%$ to $55 \%$ of the bulk organic matter throughout the core section (Figs. 8, 10). Given the present time resolution, intervals with increased but highly variable amounts of marine organic matter are identified prior to $2.05 \mathrm{Ma}$, from 1.6 to 0.76 $\mathrm{Ma}$, from 0.5 to $0.32 \mathrm{Ma}$, and at the top of the record. In general, organic petrographic results suggest a clear and, in some intervals, pronounced dominance of terrigenous organic matter. Results obtained from microscopic analysis in general are supported by pyrolytic data. Given the different sample resolution of both records, maxima in marine organic matter are to some extend paralleled by elevated hydrogen indices (e.g., at 1.72 Ma and 0.5 Ma). Dispersed terrigenous organic particles (macerals) identified under the microscope comprise sizes ranging from 40 to $50 \mu \mathrm{m}$ down to particles smaller than $2 \mu \mathrm{m}$ (submicroscopic organic matter). Large vitrinites, inertinites, and liptinites exceeding $10 \mu \mathrm{m}$ particle size are less common (on average $<20 \%$ of the bulk organic matter) than detrital fragments of them (Fig. 8). Significant variations in the proportion of detrital vs. large macerals were not observed throughout the past $2.2 \mathrm{Ma}$ considering a total range of the detrital organic fraction from $70 \%$ to $84 \%$. Larger terrigenous macerals frequently reveal plate-shaped, entirely preserved cell tissues of higher plant material with open lumina or stalky, tube-shaped morphologies, presumably reflecting transportation channels of herbaceous or grass plant material. Different levels of oxidation were recognized on these terrigenous macerals based on reflectance characteristics. Gradational changes in oxidation were observed along single, large-scale vitrinitic bodies that are interpreted to indicate thermal alteration of terrigenous organic material likely related to burning of vascular plant material.

The $\delta^{13} \mathrm{C}_{\text {org }}$ signature of Hole 959C samples reveals persistently heavy values ranging from $-18 \%$ o to $-21 \%$ (Figs. 8,10 ). In sediments younger than $0.95 \mathrm{Ma}$, high-amplitude fluctuations with minimum and maximum values below $-20.5 \%$ and close to $-18 \%$, respectively, are recorded. Given the low time resolution of the $\delta^{13} \mathrm{C}_{\mathrm{org}}$ record, relatively short-term variations in the composition of the sed- 
Figure 8. Contents and accumulation rates of total organic carbon (ARTOC), hydrogen index (HI; original $=$ open circles, mineral-matrix corrected $=$ solid circles), $\delta^{13} \mathrm{C}_{\text {org }}$ values, percentages of marine organic matter (MOM = solid circles) and bulk detrinite $<10-\mu \mathrm{m}$ particle size (open circles), and $\mathrm{C}_{\mathrm{org}} / \mathrm{N}_{\text {tot }}$ ratios $(\mathrm{C} / \mathrm{N})$ derived from organic petrologic analysis vs. time at Hole 959C.

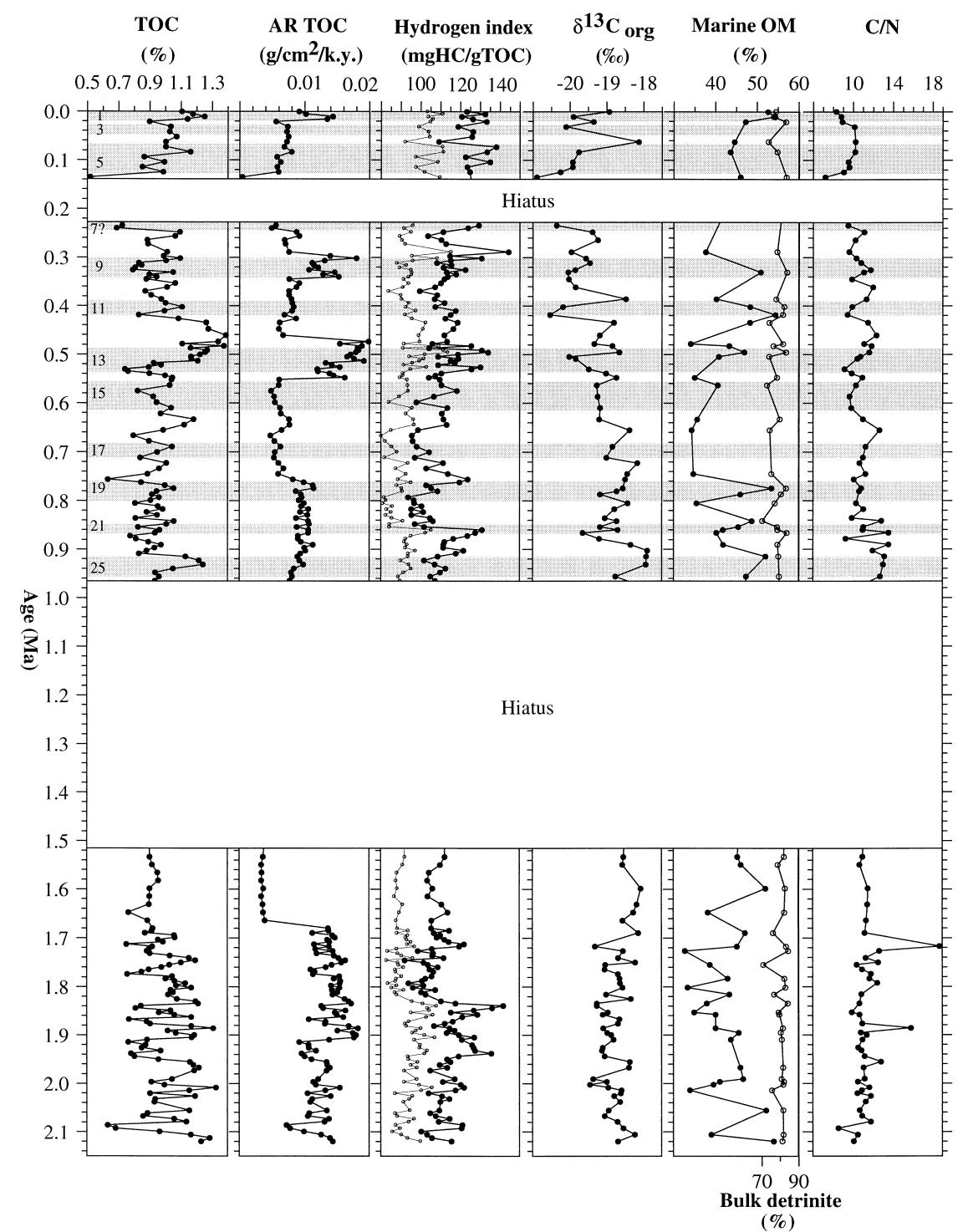

DISCUSSION

imentary organic carbon are indicated, assuming that the isotopic signal is not biased by other effects (see Tyson, 1995, for review). Amplitudes of isotopic variations, however, narrow with increasing core depth and finally level off at a relatively constant niveau prior to 0.9 Ma. Throughout the lower section of Hole 959C isotopic values scatter around $-18 \%$ and $-19 \%$, suggesting continuous preservation of marine organic carbon.

Comparison of the calculated relative proportions of marine organic carbon based on the $\delta^{13} \mathrm{C}_{\text {org }}$ signal, using -18\%o as marine and $-27 \%$ os terrigenous end-member, with results obtained from maceral analysis illustrate the offset between the two records (Fig. 10). The total difference of marine organic carbon between both profiles ranges from $17 \%$ to $61 \%$. In addition, a frequent anti-correlation displayed by opposite trends in both curves is obvious at certain levels of the record (i.e., at $2.0 \mathrm{Ma}, 1.72 \mathrm{Ma}, 0.81 \mathrm{Ma}$, and 0.4 Ma). The highest amplitudes in deviation occur in sections younger than 0.6 $\mathrm{Ma}$, whereas in older sections differences level off. The importance of the observed discrepancy between the two quantitative estimates of marine organic carbon with regard to the paleoceanographic interpretation is apparent when individual accumulation rates are discussed (Fig. 10). Absolute flux rates are frequently offset by a factor of two or even more, especially in sections where general trends are opposite. Consequently, both records would result in a distinctly different reconstruction of changes in absolute paleoproductivity off the Ivory Coast/Ghana.
Interpretation of carbonate and organic carbon records at Hole 959C with regard to African paleoclimate or paleoceanographic changes off the Ivory Coast/Ghana is limited by the maximum time resolution obtainable from condensed Pliocene-Pleistocene sections. Because of persistently low mean sedimentation rates ranging from 0.1 to $2.3 \mathrm{~cm} / \mathrm{k}$.y. and bulk sediment records at $10-\mathrm{cm}$ spacings, the best time resolution achievable does not exceed $4.3 \mathrm{k} . \mathrm{y}$. and on average is about $10 \mathrm{k} . \mathrm{y}$. It is well established for the eastern equatorial Atlantic that late Quaternary marine sedimentation was mainly forced by changes in the trade and monsoon wind zonality following the 23k.y. precessional and 100-k.y. eccentricity cycles in the Earth's orbit (Pokras and Mix, 1985; Prell and Kutzbach, 1987; deMenocal et al. 1993; Verardo and McIntyre, 1994; Schneider et al., 1996). Considering time resolution accessible at Hole 959C, both glacial/interglacial cyclicities should roughly be documented by variations in carbonate and organic carbon records, whereas climatic variations occurring along shorter time scales are probably not resolved. Sand and carbonate records of Hole 959C show repetitive minima/maxima related to orbital glacial/interglacial cycles, although frequently opposite to the pattern that has been reported from pelagic areas of the eastern equatorial Atlantic (Bickert and Wefer, 1996).

Persistently low mean sedimentation rates at Hole 959C were not expected considering the shallow water depth of $2100 \mathrm{~m}$ and the vi- 


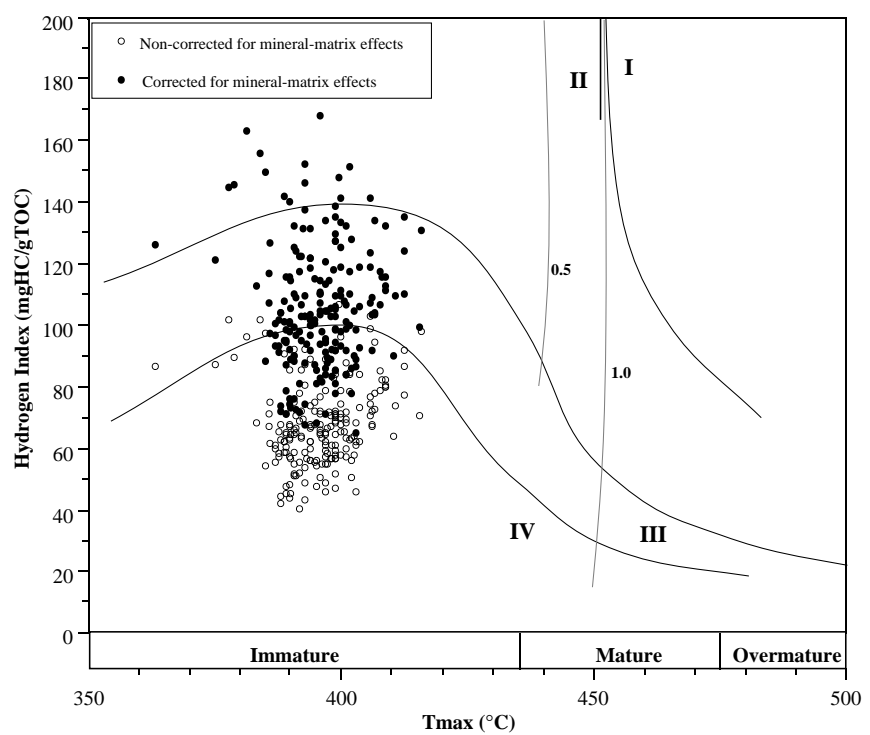

Figure 9. Results of Rock-Eval pyrolysis obtained from Pliocene-Pleistocene sections of Hole $959 \mathrm{C}$ shown as hydrogen index vs. $\mathrm{T}_{\max }$ diagram. Hydrogen indices are shown for original (open circles) and mineral-matrix corrected (solid circles) data. Kerogen types (solid lines), approximate position of vitrinite reflectance isolines (stippled lines), and general levels of thermal maturity are shown modified after Tyson (1995).

cinity to the west African continent (Fig. 1). Based on LSR reported from cores taken at water depths between 3500 and $4000 \mathrm{~m}$ in the Guinea Basin (Bickert and Wefer, 1996) and the central equatorial Atlantic (deMenocal et al., 1993; Verardo and McIntyre, 1994) rates between 3 and $4 \mathrm{~cm} / \mathrm{k} . \mathrm{y}$. or even higher were anticipated for Pliocene-Pleistocene deposits of Hole 959C (Mascle, Lohmann, Clift, et al., 1996). Condensed sections drilled at Hole 959C imply that the general biogenous and terrigenous deposition was strongly affected by processes causing intensive sediment redistribution throughout the Pliocene-Pleistocene. Slumping or other evidence for effective sediment mobilization caused by downslope mass movements are not recognizable from the lithologic core descriptions (Mascle, Lohmann, Clift, et al., 1996; Giresse et al., Chap. 43, this volume). Alternatively, persistent winnowing because of enforced bottom currents seems a reasonable mechanism to explain low LSR encountered at Hole 959C. Sedimentological and clay mineralogical evidence presented by Giresse et al. (Chap. 43, this volume) clearly support this assumption. Considering even more condensed and partly eroded core sections at Site 960 (Mascle, Lohmann, Clift, et al., 1996), drilled right on the top of the transform margin a few kilometers southeast of Hole 959 (Fig. 1A, see insert map), upward deflection and subsequent focussing of the westward flowing Equatorial Under Current (EUC) along the very steep transform margin has probably caused the establishment of elevated bottom-water velocities at the top of the ridge. Bottom-water velocities gradually decreased northwestward with increasing distance from the crest (i.e. toward the position of Hole 959C). At the position of Site 960, enforced bottom waters temporarily exceeded critical velocities causing erosional processes, but were already considerably reduced at Hole 959C, as is suggested by highly condensed but still complete oxygen isotope, sand fraction, and carbonate records.

\section{Pliocene-Pleistocene Sand and Carbonate Cycles: A Mixed "Pacific/Atlantic-Type" Pattern off the Ivory Coast/Ghana}

Cyclic variations in bulk carbonate and sand contents of deep sea sediments are closely related to Pliocene-Pleistocene glacial/interglacial changes (Berger, 1973; Crowley, 1985; Le and Shackleton,

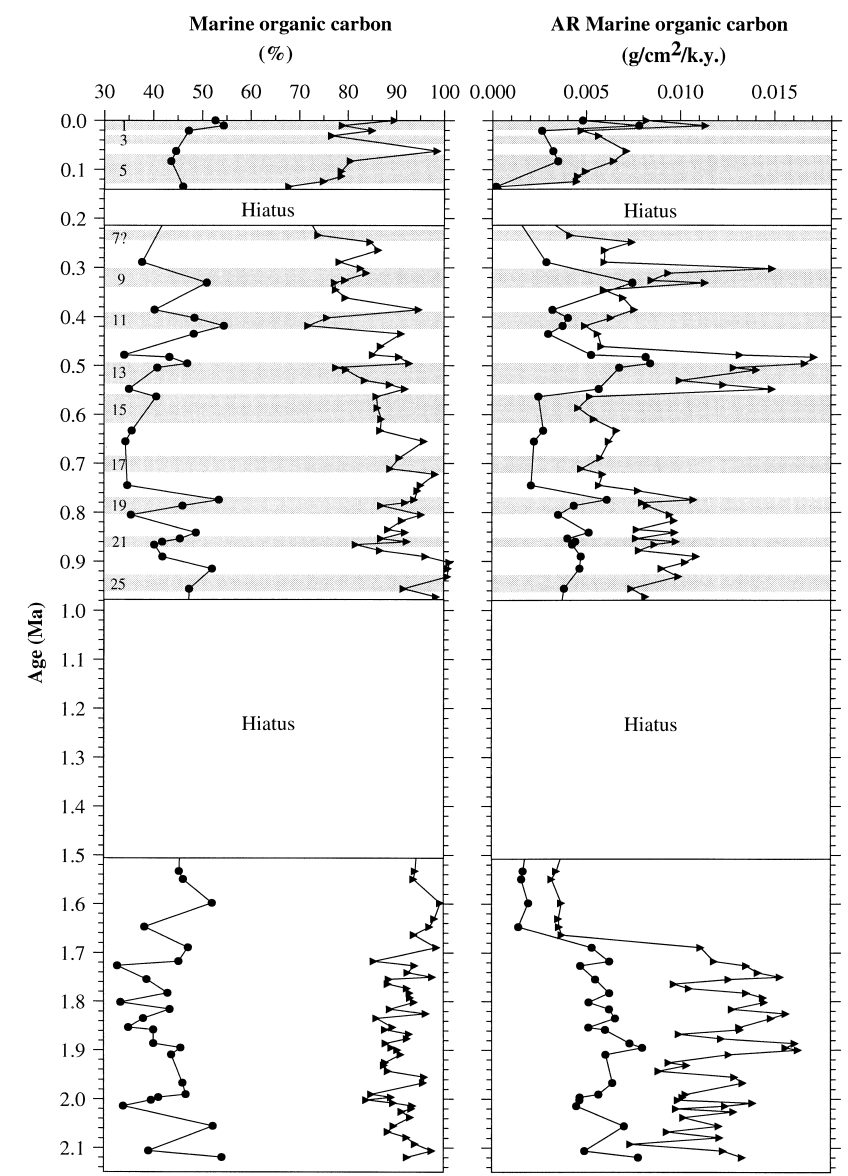

Figure 10. Comparison of calculated relative proportions of marine organic carbon based on $\delta^{13} \mathrm{C}_{\text {org }}$ (solid triangles; using $-18 \%$ o as marine and $-27 \%$ as terrestrial end-members) and organic petrological (marine macerals; solid circles) data, respectively, and corresponding accumulation rates of marine organic carbon vs. time at Hole 959C. Positions of interglacial stages (light gray bars) are shown for illustration.

1992; Howard and Prell, 1994; Verardo and McIntyre, 1994; Bickert and Wefer, 1996, Mix and Morey, 1996). There is, however, a distinct difference in the carbonate dissolution pattern of Atlantic and Pacific sediments that is attributed to changes in the basin-to-basin exchange caused by variations in the formation of North Atlantic Deep Water (NADW; Berger, 1973; Crowley, 1985; Farrell and Prell, 1989; Le and Shackleton, 1992). Whereas in the Atlanticcarbonate dissolution was enhanced during glacial periods in response to the temporal shutdown of NADW formation in the Nordic Seas and the corresponding northward propagation of corrosive bottom waters from southern ocean areas, carbonate dissolution in the Pacific mainly occurred during the transition from interglacials to glacials driven for the most part by the rate of change in climate. Glacial/interglacial changes in carbonate dissolution are extensively studied in the equatorial and southern Atlantic (Reid, 1989; Verardo and McIntyre, 1994; Bickert and Wefer, 1996). Carbonate dissolution may also be controlled by changes in the rate of organic matter decay at the sea floor (Emerson and Bender, 1981; Jahnke et al., 1994) suggesting that changes in paleoproductivity potentially result in glacial/interglacial dissolution cycles (Verardo and McIntyre, 1994; Bickert and Wefer, 1996). In addition, sand and carbonate cycles may be simulated by changes in the intensity of winnowing in response to variations in bottom-current velocities (Wu and Berger, 1991; Berger and Stax, 1994; Bickert and Wefer, 1996). According to this mechanism, higher sand contents, corresponding to higher amounts in bulk carbonate, indicate stronger bottom-water velocities, whereas lower sand con- 
tents, corresponding to lower amounts of bulk carbonate, reveal weak bottom currents.

Modern deep-water circulation in the South Atlantic is dominated by the interfingering of the southward flowing NADW and the northward flowing Circumpolar Deep Water (CDW). Related to their density properties, NADW occupies the depth interval between 2000 and $4000 \mathrm{~m}$, whereas CDW covers the deep basins below $4000 \mathrm{~m}$ (Reid, 1989; Bickert and Wefer, 1996). Exchange of CDW to the eastern basins is restricted by the Mid-Atlantic and Walvis Ridges (van Bennekom and Berger, 1984; Shannon and Chapman, 1991). In the eastern South Atlantic the lysocline did not rise above $\sim 3800 \mathrm{~m}$ water depth throughout the late Pleistocene (Curry and Lohmann, 1983; Verardo and McIntyre, 1994; Bickert and Wefer, 1996), hence inflow of CDW to the Guinea Basin during past glacial/interglacial cycles does not seem of importance. Instead productivity-driven carbonate dissolution, is proposed for the eastern equatorial Atlantic below the center of the Equatorial Divergence Zone (Verardo and McIntyre, 1994; Bickert and Wefer, 1996). This process may have caused modifications of the sand and carbonate records observed at Hole 959C.

"Atlantic-type" sand and carbonate patterns, revealing inverse correlation of TOC and bulk carbonate or sand contents, are observed in the lower section of Hole 959C although not strictly bound to gla$\mathrm{cial} /$ interglacial cycles. Hence, productivity-driven formation of carbonate and sand cycles is proposed at Hole 959C prior to 0.9 Ma. This pattern periodically changed during the last 0.9 Ma revealing positively correlated TOC, carbonate and sand records in glacial Stages 22-24, 16, 12, 8, and 4. Glacially enhanced sand and carbonate records, however, are typically observed in the Pacific Ocean ("Pacific-type" pattern) suggesting that processes controlling marine sedimentation off the Ivory Coast/Ghana changed significantly from about 0.9 Ma on. "Pacific-type" patterns have not yet been described from the eastern equatorial Atlantic but are reported from late Quaternary deposits of the Walvis Ridge area (Bickert and Wefer, 1996). As a result of the very low productivity along the Walvis Ridge, the authors conclude that the sand percent record is influenced by the varying intensity of bottom-water currents rather than by carbonate dissolution. With regard to the comparable pattern observed off the Ivory Coast/Ghana and the very steep topography along the transform margin, a similar driving mechanism is favored to explain the formation of "Pacific-type" sand records. Taking the persistently low LSR throughout the Pliocene-Pleistocene into account, it is concluded that bottom-water intensities were generally elevated at Hole $959 \mathrm{C}$, but fluctuated since about $0.9 \mathrm{Ma}$ as a result of glacial/interglacial climatic contrasts. "Pacific-type" carbonate and sand patterns observed during glacial Stages 22-24, 16, 12, 8, and 4 document the periods of highest bottom-water intensities along the northern Gulf of Guinea.

\section{Accumulation of Marine Organic Carbon: Implications for the Occurrence and Preservation Potential of Paleoproductivity Changes off the Ivory Coast/Ghana}

Accumulation of marine and terrigenous organic carbon in marine environments is mainly a function of the rate of supply and the rate of preservation (Müller and Suess, 1979; Demaison and Moore, 1980; Arthur et al., 1984; Tissot and Welte, 1984; Emerson and Hedges, 1988; Stein, 1991; Calvert and Pedersen, 1992). Evidence from biomarker analysis performed on aerosol collected above the Atlantic (Simoneit, 1977; Chesselet et al., 1981) and the Pacific Ocean (Chesselet et al., 1981; Gagosian and Peltzer, 1985; Zafiriou et al., 1985; Gagosian et al., 1987) implies that proportions of terrigenous organic matter that potentially reach the seafloor are much higher than commonly assumed (Prahl and Muehlhausen, 1989; Calvert and Pedersen, 1992). This consideration is based on the fact that vascular plant matter reveals a higher resistivity to oxic decomposition than marine organic matter and therefore, after surviving longdistance transport to the marine environment, is selectively preserved in the sedimentary record (Tissot and Welte, 1984). Changes in the accumulation of terrigenous organic matter in marine deposits therefore mainly document variations in terrigenous supply rather than changes in preservation (Stein et al., 1989). In contrast, changes in the accumulation of autochthonous organic matter under oxic water conditions, in most cases, document the combination of both processes (i.e., changes in paleoproductivity [supply] and diagenetic overprint [preservation]).

Modern coastal upwelling occurs off the Ivory Coast/Ghana during the boreal winter in response to the lateral displacement of the Intertropical Convergence Zone (ITCZ) and the corresponding trade and monsoon wind systems (Voiturez and Herbland, 1982; Verstraete, 1992). The lateral extension of the upwelling area off the Ivory Coast/Ghana marginally covers the position of Hole 959C (Fig. 1A). Modern annual primary production in the eastern equatorial Atlantic is $\sim 75$ to $90 \mathrm{~g} \mathrm{C} / \mathrm{m}^{2} / \mathrm{yr}$ (Schemainda et al., 1975; Berger, 1989). Following Müller and Suess (1979), about 1.4 to $1.8 \mathrm{~g} \mathrm{C} / \mathrm{m}^{2} / \mathrm{yr}$, equivalent to about $2 \%$ of the annual primary production, is expected to reach the sediment floor at the position of Hole 959C. Surface sediments from almost the same position reveal heavy $\delta^{13} C_{\text {org }}$ values around $-19 \%$, which suggests a dominance of marine organic carbon exceeding $90 \%$ of the bulk TOC based on a two-component mixing equation (Westerhausen et al., 1993). Isotopic values measured in near-surface samples of Hole 959C are consistent with these data. Interestingly, results from organic petrology suggest an almost $40 \%$ lower proportion of marine organic carbon than is estimated from $\delta^{13} \mathrm{C}_{\text {org }}$ values. Corresponding hydrogen indices below $150 \mathrm{mg} \mathrm{HC} / \mathrm{g}$ TOC support microscopic estimates, assuming that an almost entirely marine organic composition of sedimentary organic carbon should result in distinctly higher hydrogen indices (Stein, 1991). The evident discrepancy between the isotopic signal and other organic geochemical data suggests an additional depositional factor, which probably is attributed to the eolian fraction of terrigenous organic material (see discussion below).

Persistent low LSR at Hole 959C suggest oxic bottom- and porewater conditions during times of deposition, causing increased residence times of organic matter at the sediment-water interface (Emerson et al., 1985; Emerson and Hedges, 1988; Jumars et al., 1989; Reimers, 1989; Rowe et al., 1990). These conditions did not favor the preservation of paleoproductivity changes off the Ivory Coast/Ghana. Nevertheless, short-term variations in paleoproductivity are still preserved, given the rather low time resolution at Hole 959C. Changes in the total content and accumulation rate of marine organic carbon, deduced from $\delta^{13} C_{\text {org }}$ or organic petrographic records of Hole 959C, evidence short-term increased deposition of marine organic carbon prior to 1.7 Ma during isotopic Stages 25-19, 14-12, 9, and the Holocene (Fig. 10). Elevated hydrogen indices corroborate this interpretation. Paleoproductivity in the pelagic Gulf of Guinea was enhanced during specific glacials, e.g. Stages 6 or 2 (Verardo and McIntyre, 1994; Schneider et al., 1996). By contrast, off the Ivory Coast/Ghana, intensified coastal upwelling is also suggested during interglacial Stages $21,19,13,9$, and 1, probably caused by local oceanographic and climatic conditions along the continental margin.

\section{Accumulation of Terrigenous Organic Carbon off the Ivory Coast/Ghana: Evidence for Changes in Eolian Supply of C4 Plant Debris from Central Africa}

Accumulation of terrigenous material in the equatorial Atlantic is closely related to the glacial/interglacial history of atmospheric dust supply from central and western Africa (Ruddiman and Janecek, 1989; Sarnthein et al., 1982; see deMenocal et al., 1993, for review). Eolian material reaches the modern eastern equatorial Atlantic off the Ivory Coast/Ghana during the boreal winter because of the southernmost position of the dust plume (Ruddiman and Janecek, 1989; Bonifay and Giresse, 1992; Fredoux, 1994; Fig. 1B). Studies discussing the supply of terrigenous organic matter to the equatorial Atlantic are 
based on biomarker evidence (Simoneit, 1977; Chesselet et al., 1981; Poynter et al. 1989, ten Haven et al., 1989), abundances of freshwater diatoms (Pokras and Mix, 1985; Pokras and Ruddiman, 1989; deMenocal et al., 1993), and palynomorphs (Maley, 1982; Turon, 1984; Lézine and Hooghiemstra, 1990; Lézine, 1991; Dupont and Agwu, 1991; Frédoux, 1994), or other terrigenous markers, such as detrital charcoal identified in sediments below the center of the Equatorial Divergence Zone (Verardo and Ruddimann, 1996). Sources for most of these highly resistant fragments of terrestrial plants are the shrub and grass savannah-covered regions of the Sahel and Sahara zones (Prospero, 1981; Ruddiman and Janecek, 1989; Bonifay and Giresse, 1992; Pokras and Mix, 1985; Fig. 1). The repetitive lateral displacement of African vegetation zones related to glacial/interglacial climatic changes are well preserved in sediments of the deep Guinean Basin (Fredoux, 1994). According to this study, glacial periods are considered dry stages, showing an increase of the Graminae, SaheloSaharan, and Sudanian pollen groups, whereas interglacial periods are considered humid, with an increase of the Mangrove and Guinean Rain Forest pollen groups. African hyperarid conditions developed as a result of increased wind speeds, which probably caused and fueled extensive natural bush or savannah fires (Pokras and Mix, 1985). According to this scenario huge amounts of burned (or coked) plant material were injected into the atmosphere and subsequently transported to the equatorial Atlantic. Witness of these extensive fires are phytholiths (grass cuticles) or charcoal fragments identified in glacial sections in the central equatorial Atlantic (Pokras and Mix, 1985; deMenocal et al., 1993; Verardo and Ruddimann, 1996).

Terrigenous organic carbon accumulation at Hole 959C dominates the bulk organic composition throughout the Pliocene-Pleistocene if quantitative estimates based on organic petrologic and Rock-Eval records are considered. Dominance of the allochthonous organic fraction is likely to be the result of intense selective remineralization of the labile (marine) organic fraction. However, if changes in the accumulation of terrigenous organic matter in general reflect variations in supply (Stein et al., 1989) 959C records suggest that eolian input continuously influenced sedimentation off the Ivory Coast/ Ghana throughout the past $2.2 \mathrm{~m}$.y. Missing glacial/interglacial variations in the accumulation of terrigenous organic carbon might partly be explained by low LSR and intensive sediment redistribution, causing a persistent mixing of surface and subsurface sediments. At the present stage however, it remains, enigmatic why sand and carbonate records of Hole 959C were not affected in the same way regarding the clearly preserved glacial/interglacial cycles.

The $\delta^{13} \mathrm{C}_{\text {org }}$ records of modern and Quaternary marine deposits are commonly applied to evaluate the relative proportions of marine and terrigenous organic carbon using a two-component mixing equation (Müller et al., 1983; Jasper and Gagosian, 1990; Stein, 1991; Westerhausen et al., 1993; Müller et al., 1994; Schneider et al., 1996). Various other factors, however, such as changes in surface water $\mathrm{CO}_{2}$ concentrations or $\mathrm{C} 4$ plant supply, may considerably bias the isotopic signal of marine deposits (Müller et al., 1994; see Tyson, 1995, for review). Based on the $\delta^{13} \mathrm{C}_{\text {org }}$ record of Hole $959 \mathrm{C}$, marine proportions were estimated to range from $67 \%$ to $100 \%$. These high numbers are not in accordance with organic petrologic results, revealing an offset between $17 \%$ and $>60 \%$ (Fig. 10). With regard to the persistently low LSR at Hole 959C estimates derived from $\delta^{13} \mathrm{C}_{\text {org }}$ appear to overrate marine organic proportions. Marine organic carbon inferred from $\delta^{13} \mathrm{C}_{\text {org }}$ commonly uses marine and terrigenous isotopic endmember values of about $-19 \%$ and $-27 \%$, respectively (Schneider et al., 1996). The terrigenous endmember is indicative for land plant material following the $\mathrm{C} 3$ photosynthetic pathway (Gearing, 1988). There is, however, a second group of terrigenous plants, which is specially adapted to dry climatic habitats, that uses the C4 photosynthesis pathway (Smith and Epstein, 1971; Gearing, 1988). C4 plants exhibit extremely heavy $\delta^{13} \mathrm{C}_{\text {org }}$ signatures around $-12 \%$ o and comprise most of the Gramineae, which are dominant in savannah-covered areas of African tropical lowlands (Giresse et al., 1994).
Eolian dust released to the Gulf of Guinea originates from typical habitats of $\mathrm{C} 4$ plant vegetation (Fig. 1), so air-blown particulate organic matter in sediments of the Gulf of Guinea is expected to contain some admixture of $\mathrm{C} 4$ plant debris. $\mathrm{C} 4$ plant material, however, will have a strong effect on the bulk sedimentary $\delta^{13} C_{\text {org }}$ signal, causing a shift to more positive values, which, in turn, suggests higher proportions of marine organic matter. Based on this consideration, profiles of Hole 959C were re-evaluated, and C4 plant concentrations required to compensate for the observed offset between the isotopic and organic petrologic records were calculated. Accordingly $\mathrm{C} 4$ plant concentrations and accumulation rates range from $10 \%$ to $37 \%$ and almost zero to $0.006 \mathrm{~g} / \mathrm{cm}^{2} / \mathrm{k} . y$., respectively (Fig. 11). The highest $\mathrm{C} 4$ plant concentrations are clearly correlated to glacial stages comparable to other paleodust proxies. Total ranges of $\mathrm{C} 4$ plant estimates are supported by similar relative abundances of Gramineae and Cyperaceae pollen reported from late Quaternary sediments of the adjacent deep Guinean Basin (Frédoux, 1994). Additional evidence for the presence of grass-type debris in sediments of Hole 959C is derived from organic petrologic results. Commonly observed tubeshaped, elongated particles revealing different levels of oxidation likely represent partly burned fragments of a former grass-type vegetation that possibly originated from central African savannah vegetation. However, it still remains an open target to prove the $\mathrm{C} 4$ plant origin of these terrestrial macerals. Considering total flux rates of $\mathrm{C} 4$ plant material to the northern Gulf of Guinea, eolian supply was strongly intensified prior to $1.68 \mathrm{Ma}$, and during glacial Stages 2224, 20, 14, and 12 (Fig. 11). These results in general are supported by first biomarker evidence from lignite oxidation products measured in Pliocene-Pleistocene sediments from Hole 959C (Giresse et al., Chap. 43, this volume). Giresse and coauthors report elevated cinnamyl/vanillyl ratios $(\mathrm{C} / \mathrm{V})$, which are indicative for $\mathrm{C} 4$ grass-type vegetation (Hedges and Mann, 1979; Hedges and Ertel, 1982), at certain levels of Hole 959C (i.e., during isotopic Stage 4 at 1.7 Ma and at $1.8 \mathrm{Ma}$ ). Comparison with estimated $\mathrm{C} 4$ plant contents and accumulation rates presented here (Fig. 11) reveals a fairly good temporal coincidence, especially if the low sample resolution of both analytical approaches is taken into account. Results of this study have shown, that application of quantitative organic petrology in combination with other established organic geochemical approaches (i.e., of $\delta^{13} \mathrm{C}_{\mathrm{org}}$ ), provide new information on the composition of sedimentary organic matter that have to be considered when the depositional history of marine and terrestrial organic matter is reconstructed.

\section{SUMMARY}

The Pliocene-Pleistocene history of carbonate and organic carbon accumulation was reconstructed for the eastern equatorial Atlantic off the Ivory Coast/Ghana (Hole 959C) using bulk carbonate, sand fraction, organic carbon, and other organic geochemical records $\left(\delta^{13} C_{\text {org }}\right.$, marine organic matter percentages derived from organic petrology, hydrogen index, $\mathrm{C} / \mathrm{N}$ ). In general, biogenous and terrigenous sedimentation is strongly affected by low mean sedimentation rates that are attributed to persistently enhanced bottom-water velocities causing winnowing and sediment redistribution close to the top of the transform margin.

Given the low time resolution at Hole 959C, sand and carbonate carbon records reveal glacial/interglacial cycles likely responding to orbital forcing. Carbonate contents and accumulation rates in general are reduced compared to records obtained from pelagic areas of the eastern equatorial Atlantic because of sediment redistribution superimposed by terrigenous dilution. Cyclic sand and carbonate maxima, inversely correlated to low TOC contents, dominate during glacials prior to about $0.9 \mathrm{Ma}$. This pattern, typically known in the Atlantic Ocean, indicates mainly productivity-driven carbonate dissolution related to changes in paleoproductivity along the continental margin off the Ivory Coast/Ghana. During glacial Stages 22-24, 20, 16, 12, 


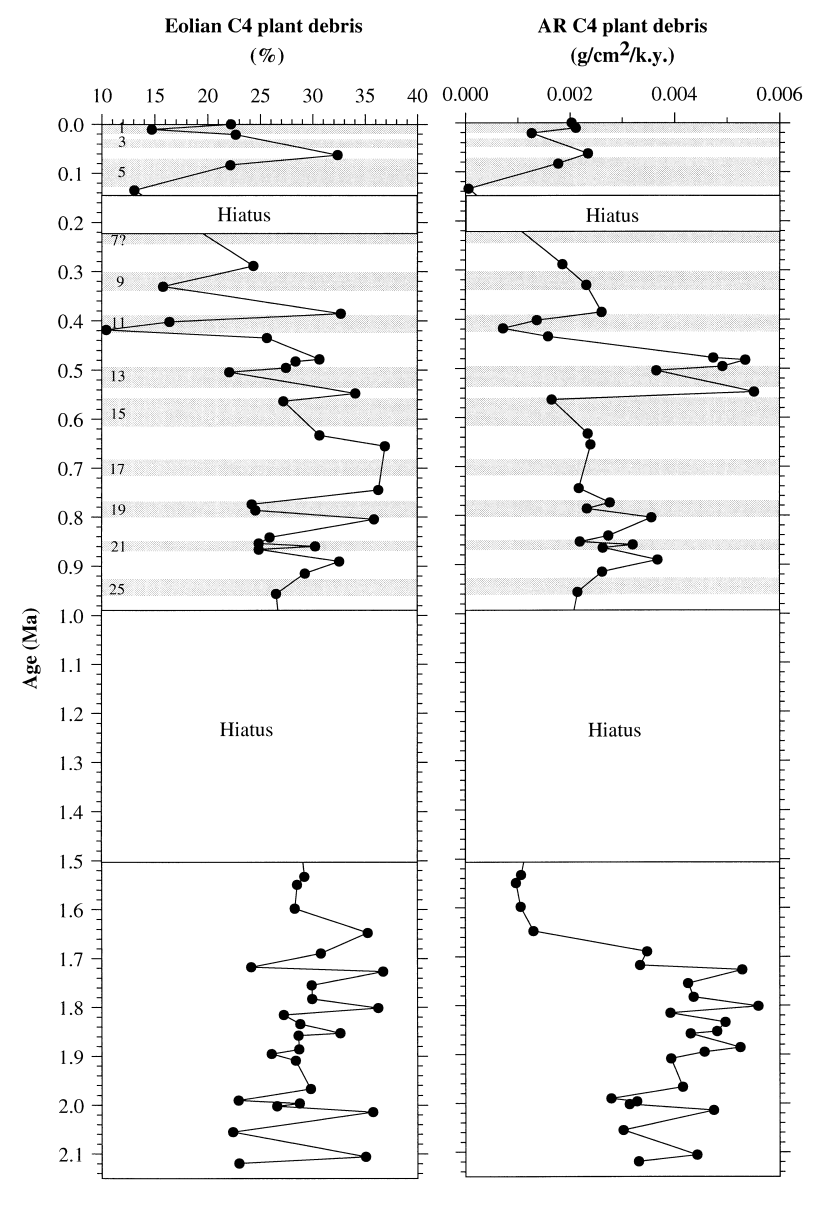

Figure 11. Estimated Pliocene-Pleistocene contents and accumulation rates of C4 plant debris observed at Hole 959C. Interglacial isotopic stages (light gray bars) are shown for illustration.

8 , and 4 mechanisms controlling sedimentation temporarily changed at Hole 959C, as indicated by positive correlated maxima in sand, carbonate, and TOC contents. This pattern is typically observed in sediments of the Pacific Ocean. Formation of "Pacific-type" sand and carbonate cycles off the Ivory Coast/Ghana is attributed to drastically increased bottom-water intensities along the transform margin in accordance with results reported from the Walvis Ridge area (Bickert and Wefer, 1996).

Accumulation of organic carbon at Hole 959C is strongly influenced by low sedimentation rates that likely favored intensive remineralization of the labile (marine) organic fraction. Nevertheless, short-term glacial_interglacial changes in paleoproductivity off the Ivory Coast/Ghana are to some extend recognizable during glacials prior to 1.7 Ma and during interglacial Stages 21, 19, 13, 9, and 1. Enhanced coastal upwelling during interglacials is attributed to local paleoclimatic and oceanographic conditions off the Ivory Coast/Ghana. Quantitative estimates of marine organic carbon based on organic petrologic and $\delta^{13} \mathrm{C}_{\text {org }}$ records reveal an offset ranging from $17 \%$ to $60 \%$. The highest variabilities between both records are documented back to $\sim 0.9 \mathrm{Ma}$. Discrepancies between the isotopic and microscopic records are attributed to admixture of $\mathrm{C} 4$ plant debris reaching the eastern equatorial Atlantic via atmospheric dust. Terrestrial organic material likely originated from the grass savannah-covered Sahel zone in central Africa. Estimated C4 plant concentrations and accumulation rates range from $10 \%$ to $37 \%$ and almost zero to $0.006 \mathrm{~g}$ / $\mathrm{cm}^{2} / \mathrm{k}$.y., respectively. These results indicate strongest eolian supply to the northern Gulf of Guinea was between 1.9 to $1.68 \mathrm{Ma}$ and during glacial isotopic Stages 22-24, 20,14, and 12. The presence of grass-type plant debris is further supported by organic petrologic studies revealing well-preserved cell tissues of vascular plants and tube-shaped, elongated terrestrial macerals showing different levels of oxidation.

\section{ACKNOWLEDGMENTS}

The $\delta^{13} \mathrm{C}_{\text {org }}$ and total nitrogen data were provided by P. Müller and M. Segel (Department of Geosciences, Bremen University). Oxygen and carbon isotopic data of benthic foraminifers were kindly supplemented by G.P. Lohmann (Woods Hole Oceanographic Institution). T. Bickert essentially contributed to the establishment of an age model based on the oxygen isotope record. I would also like to thank P.J. Müller, R. Stein, and one anonymous reviewer for their helpful suggestions to improve the manuscript. Technical assistance in the laboratories was performed by H. Buschhoff, J. Funk, R. Henning, K. Junghyun, U. Langrock, B. Meyer-Schack, and H. Orthey. B. Coll improved the English. This study was supported by the Deutsche Forschungsgemeinschaft, grant "Wa 1036/3-1."

\section{REFERENCES}

Abrantes, F., 1992. Paleoproductivity oscillations during the last $130 \mathrm{ka}$ along the Portuguese and NW African margins. In Summerhayes, C.P., Prell, W.L., and Emeis, K.C. (Eds.), Upwelling Systems: Evolution Since the Early Miocene. Geol. Soc. Spec. Publ. London, 64:463-448.

Arthur, M.A., Dean, W.E., and Stow, D.A.V., 1984. Models for the deposition of Mesozoic-Cenozoic fine-grained, organic-carbon-rich sediment in the deep-sea. In Stow, D.A.V., and Piper, D.J.W (Eds.), Fine-Grained Sediments: Deep-Water Processes and Facies. Geol. Soc. Spec. Publ. London, 15:527-560.

Berger, W.H., 1973. Deep-sea carbonates: Pleistocene dissolution cycles. J. Foraminiferal Res., 3:187-195.

, 1989. Global maps of ocean productivity. In Berger, W.H., Smetacek, V.S., and Wefer, G. (Eds.), Productivity of the Oceans: Present and Past: New York (Wiley), 429-455.

Berger, W.H., and Herguera, J.C., 1992. Reading the sedimentary record of the ocean's productivity. In Falkowski, P.G., and Woodhead, A.D. (Eds.), Primary Productivity and Biogeochemical Cycles in the Sea: New York (Plenum), 455-486.

Berger, W.H., and Stax, R., 1994. Neogene carbonate stratigraphy of the Ontong Java Plateau (western equatorial Pacific). Terra Nova, 6:520534.

Berger, W.H., Yasuda, M.K., Bickert, T., Wefer, G., and Takayama, T., 1994. Quaternary time scale for the Ontong Java Plateau: Milankovitch template for Ocean Drilling Program Site 806. Geology, 22:463-467.

Bickert, T., and Wefer, G., 1996. Late Quaternary deep-water circulation in the South Atlantic: reconstruction from carbonate dissolution and benthic stable isotopes. In Wefer, G., Berger, W.H., Siedler, G. (Eds.), The South Atlantic: Present and Past Circulation: Berlin (Springer), 599-620.

Bonifay, D., and Giresse, P., 1992. Middle to late Quaternary sediment flux and post-depositional processes between the continental slope off Gabon and the Mid-Guinean margin. Mar. Geol., 106:107-129.

Calvert, S.E., and Pedersen, T.F., 1992. Organic carbon accumulation and preservation in marine sediments: how important is anoxia? In Whelan, J.K., and Farrington, J.W. (Eds.), Organic Matter: Productivity, Accumulation and Preservation in Recent and Ancient Sediments: New York (Columbia Univ. Press), 231-263.

Calvert, S.E., and Price, N.B., 1983. Geochemistry of Namibian Shelf sediments. In Thiede, J., and Suess, E. (Eds.), Coastal Upwelling: Its Sedimentary Record (Pt. A): New York (Plenum), 337-376.

Chesselet, R., Fontugne, M., Buat-Menard, P., Ezat, U., and Lambert, C.E., 1981. The origin of particulate organic carbon in the marine atmosphere as indicated by its stable carbon isotopic composition. Geophys. Res. Lett., 8:345-348.

Combaz, A., Bellet, J., Poulain, D., Caratini, C., and Tissot, C., 1974. Étude microscopique de la matière organique de sédiments quaternaires de Mer de Norvège. In Marines, C.de G. (Ed.), Orgon I Mer de Norvège: Paris (CNRS), 81-139.

Crowley, T.J., 1985. Late Quaternary carbonate changes in the North Atlantic and Atlantic/Pacific comparisons. In Sundquist, E.T., and Broecker, W.S. (Eds.), The Carbon Cycle and Atmospheric $\mathrm{CO}_{2}$ : Natural Variations, 
Archean to Present. Geophys. Monogr., Am. Geophys. Union, 32:271284.

Curry, W.B., and Lohmann, G.P., 1983. Reduced advection into Atlantic Ocean deep eastern basins during last glaciation maximum. Nature, 306:577-580.

Demaison, G.J., and Moore, G.T., 1980. Anoxic environments and oil source bed genesis. Org. Geochem., 2:9-31.

deMenocal, P.B., Ruddiman, W.F., and Pokras, E.M., 1993. Influence of high- and low-latitude on African terrestrial climate: Pleistocene eolian records from equatorial Atlantic Ocean Drilling Program Site 663. Paleoceanography, 8:209-242.

Droz, L., Blarez, E., Mascle, J., and Boko, S., 1985. The "Trou-Sans-Fond" deep sea fan (off Ivory Coast, Equatorial Atlantic). Mar. Geol., 67:1-11.

Dupont, L.M., and Agwu, C.O.C., 1991. Environmental control of pollen grain distribution patterns in the Gulf of Guinea and offshore NW-Africa. Geol. Rundsch., 80:567-589.

Emerson, S., and Bender, M., 1981. Carbon fluxes at the sediment-water interface of the deep-sea: calcium carbonate preservation. J. Mar. Res., 39:139-162.

Emerson, S., and Hedges, J.I., 1988. Processes controlling the organic carbon content of open ocean sediments. Paleoceanography, 3:621-634.

Emerson, S., Fischer, K., Reimers, C., Heggie, D., 1985. Organic carbon dynamics and preservation in deep sea sediments. Deep-Sea Res. Part A, 32: $1-21$.

Espitalié, J., Laporte, J.L., Leplat, P., Madec, M., Marquis, F., Paulet, J., and Boutefeu, A., 1977. Méthode rapide de caractérisation des roches mères, de leur potentiel pétrolier et de leur degré d'évolution. Rev. Inst. Fr. Pet., 32:23-42.

Farrell, J.W., and Prell, W.L., 1989. Climatic change and CaCO3 preservation: an 800,000 year bathymetric reconstruction from the central equatorial Pacific Ocean. Paleoceanography, 4:447-466.

Frédoux, A., 1994. Pollen analysis of a deep-sea core in the Gulf of Guinea: vegetation and climatic changes during the last 225,000 years B.P. Palaeogeogr., Palaeoclimatol., Palaeoecol., 109:317-330.

Gagosian, R.B., and Peltzer, E.T., 1985. The importance of atmospheric input of terrestrial organic material to deep sea sediments. Org. Geochem., 10:661-669.

Gagosian, R.B., Peltzer, E.T., and Merrill, J.T., 1987. Long range transport of terrestrially derived lipids in aerosols from the south Pacific. Nature, 325:800-803.

Gearing, J.N., 1988. The use of stable isotope ratios for tracing nearshoreoffshore exchange of organic matter. In Jansson, B.-O. (Ed.), Lecture Notes on Coastal and Estuarine Studies. Coastal-Offshore Ecosystem Interactions, 22:69-101.

Giresse, P., and Barusseau, J.-P., 1989. Quaternary accumulation rates by hemipelagic and gravity current sedimentation on the Atlantic margin of Africa: control factors of advective and vertical flows. Mar. Geol., 89:279-297.

Giresse, P., Maley, J., and Brenac, P., 1994. Late Quaternary Paleoenvironments in the Lake Barombi Mbo (West Cameroon) deduced from pollen and carbon isotopes of organic matter. Palaeogeogr., Palaeoclimatol., Palaeoecol., 107:65-78.

Hart, T.J., and Currie, R.I., 1960. The Benguela Current. Disc. Rep., 31:123298.

Hay, W.W., and Brock, J.C., 1992. Temporal variation in intensity of upwelling off southwest Africa. In Summerhayes, C.P., Prell, W.L., and Emeis, K.C. (Eds.), Upwelling Systems: Evolution Since the Early Miocene. Geol. Soc. Spec. Publ. London, 463-497.

Hedges, J.I., and Ertel, J.R., 1982. Characterization of lignin by capillary gas chromatography of cupric oxide oxidation products. Anal. Chem., 54:174-178.

Hedges, J.I., and Mann, D.C., 1979. The lignin geochemistry of marine sediments from the southern Washington coast. Geochim. Cosmochim. Acta, 43:1809-1818.

Hölemann, J.A., and Henrich, R., 1994. Allochthonous versus autochthonous organic matter in Cenozoic sediments of the Norwegian Sea: evidence for the onset of glaciations in the northern hemisphere. Mar. Geol., 121:87103.

Howard, W.R., and Prell, W.L., 1994. Late Quaternary $\mathrm{CaCO}_{3}$ production and preservation in the Southern Ocean: implications for oceanic and atmospheric carbon cycling, Paleoceanography, 9:453-482.

Jahnke, R.A., Craven, D.B., and Gaillard, J.F., 1994. The influence of organic matter diagenesis on $\mathrm{CaCO}_{3}$ dissolution at the deep-sea floor. Geochim Cosmochim. Acta, 58:2799-2809.
Jasper, J.P., and Gagosian, R.B., 1990. The sources and deposition of organic matter in the Late Quaternary Pygmy Basin, Gulf of Mexico. Geochim. Cosmochim. Acta, 54:1117-1132.

Jones, R.W., 1987. Organic facies. Adv. Pet. Geochem., 2:1-80.

Jumars, P.A., Altenbach, A.V., de Lange, G.J., Emerson, S.R., Hargrave, B.T., Müller, P.J., Prahl, F.G., Reimers, C.E., Steiger, T., and Suess, E., 1989. Transformation of seafloor-arriving fluxes into the sedimentary record. In Berger, W.H., Smetaceck, V.S., and Wefer, G. (Eds.), Productivity of the Ocean: Present and Past: Dahlem Workshop, Life Sci. Res. Rep., 44:291-312.

Katz, B.J., 1983. Limitations of "Rock-Eval" pyrolysis for typing organic matter. Org. Geochem., 4:195-199.

Langford, F.F., and Blanc-Valleron, M.M., 1990. Interpreting Rock-Eval pyrolysis data using graphs of pyrolizable hydrocarbons vs. total organic carbon. AAPG Bull., 74:799-804.

Le, J., and Shackleton, N.J., 1992. Carbonate dissolution fluctuations in the western equatorial Pacific during the late Quaternary. Paleoceanography, $7: 21-42$.

Lézine, A.-M., 1991. West African paleoclimates during the last climatic cycle inferred from an Atlantic deep-sea pollen record. Quat. Res., 35:456-463.

Lézine, A.-M., and Hooghiemstra, H., 1990. Land-sea comparison during the last glacial-interglacial transition: pollen records from the west tropical Africa. Palaeogeogr., Palaeoclimatol., Palaeoecol., 79:313-331.

Liebezeit, G., and Wiesner, M.G., 1989. Pyrolysis of recent marine sediments. 1: Biopolymers. Org. Geochem., 16:1179-1185.

Littke, R., 1993. Deposition, Diagenesis, and Weathering of Organic MatterRich Sediments: Heidelberg (Springer-Verlag).

Lutjeharms, J.R.E., and Meeuwis, J.M., 1987. Kinematics of the upwelling front off Southern Africa: the Benguela and comparable ecosystems. $S$. Afr. J. Mar. Sci., 5:35-49.

Maley, J., 1982. Dust, clouds, rain types, and climatic variations in the Tropical North Africa. Quat. Res., 18:1-16.

Martin, L., 1974. Le Trou Sans Fond, Canyon sous-marin de la Côte d'Ivoire. Cah. O.P.-S.T.O.M., Ser. Geol., 1:67-76.

Martinson, D.G., Pisias, N.G., Hays, J.D., Imbrie, J., Moore, T.C., Jr., and Shackleton, N.J., 1987. Age dating and the orbital theory of the ice ages: development of a high-resolution 0 to 300,000-year chronostratigraphy. Quat. Res., 27:1-29.

Mascle, J., Lohmann, G.P., Clift, P.D., et al., 1996. Proc. ODP, Init. Repts., 159: College Station, TX (Ocean Drilling Program).

Mix, A.C., 1989. Pleistocene paleoproductivity: evidence from organic carbon and foraminifer species. In Berger, W.H., Smetacek, V.S., and Wefer, G. (Eds.), Productivity of the Oceans: Present and Past: New York (Wiley), 313-340.

Mix, A.C., and Morey, A.E., 1996. Climate feedback and Pleistocene variations in the Atlantic South Equatorial Current. In Wefer, G., Berger, W.H., Siedler, G., and Webb, D. (Eds.), The South Atlantic: Present and Past Circulation: Berlin (Springer-Verlag).

Müller, P.J., 1977. C/N ratios in Pacific deep sea sediments: effect of inorganic ammonium and organic nitrogen compounds sorbed by clays. Geochim. Cosmochim. Acta, 41:765-776.

Müller, P.J., Erlenkeuser, H., and von Grafenstein, R., 1983. Glacial-interglacial cycles in oceanic productivity inferred from organic carbon contents in eastern North Atlantic sediment cores. In Suess, E., and Thiede, J. (Eds.), Coastal Upwelling: Its Sediment Record (Pt. B.): New York (Plenum), 365-398.

Müller, P.J., Schneider, R., and Ruhland, G., 1994. Late Quaternary $\mathrm{PCO}_{2}$ variations in the Angola Current: evidence from organic carbon $\delta^{13} \mathrm{C}$ and alkenone temperatures. In Zahn, R., Pedersen, T.F., Kaminski, M.A., and Labeyrie, L. (Eds.), Carbon Cycling in the Glacial Ocean: Constraints on the Ocean's Role in Global Change: NATO ASI Ser. C, Heidelberg (Springer-Verlag), 17:343-366.

Müller, P.J., and Suess, E., 1979. Productivity, sedimentation rate, and sedimentary organic matter in the oceans, I. Organic carbon preservation. Deep-Sea Res. Part A, 26:1347-1362.

Peterson, R.G., and Stramma, L., 1991. Upper-level circulation in the South Atlantic Ocean. Progr. Oceanogr., 26:1-73.

Pokras, E.M., and Mix, A.C., 1985. Eolian evidence for spacial variability of late Quaternary climates in tropical Africa. Quat. Res., 24:137-149.

Pokras, E.M., and Ruddiman, W.F., 1989. Evolution of South Saharan/Sahelian aridity based on freshwater diatoms (genus Melosira) and opal phytoliths: Sites 662 and 664. In Ruddiman, W., Sarnthein, M., et al., Proc. ODP, Sci. Results, 108: College Station, TX (Ocean Drilling Program), 143-148. 
Poynter, J.G., Farrimond, P., Robinson, N., and Eglinton, G., 1989. Aeolian derived higher plant lipids in the marine sedimentary record: links with palaeoclimate. In Leinen, M., and Sarnthein, M. (Eds.), Palaeoclimatology and Palaeometeorology: Modern and Past Patterns of Global Atmospheric Transport: Dordrecht (Kluwer Academic Press), 435-462.

Prahl, F.G., and Muehlhausen, L.A., 1989. Lipid biomarkers as geochemical tools for paleoceanographic study. In Berger, W.H., Smetacek, V.S., and Wefer, G. (Eds.), Productivity of the Ocean: Present and Past. Dahlem Workshop, Life Sci. Res. Rep., 44:271-289.

Prell, W.L., and Kutzbach, J.E., 1987. Monsoon variability over the past 150,000 years. J. Geophys. Res., 92:8411-8425.

Prospero, J.M., 1981. Arid regions as sources of mineral aerosols in the marine atmosphere. In Pewe, T.L. (Ed.), Desert Dust: Origin, Characteristics, and Effects on Man. Spec. Pap.-Geol. Soc. Am., 186:71-86.

Reid, J.L., 1989. On the total geostrophic circulation of the South Atlantic Ocean: flow patterns, tracers, and transports. Progr. Oceanogr., 23:149244.

Reimers, C.E., 1989. Control of benthic fluxes by particulate supply. In Berger, W.H., Smetacek, V.S., and Wefer, G. (Eds.), Productivity of the Ocean: Present and Past: New York (Wiley), 217-233.

Rowe, G.T., Sibuet, M., Deming, J., and Khripounoff, A., 1990. Organic carbon turnover time in deep-sea benthos. Progr. Oceanogr., 24:141-160.

Ruddiman, W.F., and Janecek, T.R., 1989. Pliocene-Pleistocene biogenic and terrigenous fluxes at equatorial Atlantic Sites 662, 663, and 664. In Ruddiman, W., Sarnthein, M., et al., Proc. ODP, Sci. Results, 108: College Station, TX (Ocean Drilling Program), 211-240.

Santos, V., Billett, D.S.M., and Rice, A.L., 1994. Organic matter in deep-sea sediments of the Porcupine Abyssal Plain in the north-east Atlantic Ocean. I: Lipids. Deep-Sea Res., 41:787-819.

Sarnthein, M., Thiede, J., Pflaumann, U., Erlenkeuser, H., Fütterer, D., Koopmann, B., Lange, H., and Seibold, E., 1982. Atmospheric and oceanic circulation patterns off Northwest Africa during the past 25 million years. In von Rad, U., Hinz, K., Sarnthein, M., Seibold, E. (Eds.), Geology of the Northwest African Continental Margin: Berlin (Springer Verlag), 545604.

Schemainda, R., Nehring D., and Schulz, S., 1975. Ozeanologische Untersuchungen zum Produktionspotential der nordwestafrikanischen Wasserauftriebsregion 1970-1973. Geod. Geophys. Veroff., 4:1-88.

Schneider, R.R., Müller, P.J., Ruhland, G., Meinecke, G., Schmidt, H., and Wefer, G., 1996. Late Quaternary surface temperatures and productivity in the east-equatorial South Atlantic: response to changes in trade/monsoon wind forcing and surface water advection. In Wefer, G., Berger, W.H., Siedler, G., and Webb, D. (Eds.), The South Atlantic: Present and Past Circulation: Berlin (Springer-Verlag), 527-551.

Schütz, L., 1980. Long range transport of desert dust with special emphasis on the Sahara. In Kneip, T.J., and Lioy, P.J. (Eds.), Annals of the New York Academy of Sciences. New York Acad. Sci., 338:515-532.

Semmelhack, W., 1943. Die Staubfälle im nordwest-afrikanischen Gebiet des Atlantischen Ozeans. Ann. Hydrogr. Marit. Meteor, 62:273-277.

Shannon, L.V., and Chapman, P., 1991. Evidence for Antarctic Bottom Water in the Angola Basin at 32 $2^{\circ}$ S. Deep-Sea Res., 38:1299-1304.

Simon, P., and Amakou, B., 1984. La discordance oligocène et les dépôts postérieurs à la discordance dans le bassin sédimentaire ivoirien. Bull. Soc. Geol. Fr., 7:1117-1125.

Simoneit, B.R.T., 1977. Organic matter in eolian dusts over the Atlantic Ocean. Mar. Chem., 5:443-464.

Smith, B.N., and Epstein, S., 1971. Two categories of 13C/12C ratios for higher plants. Plant Physiol., 47:380-384.

Stach, E., Mackowsky, M.-T., Teichmüller, M., Taylor, G.H., Chandra, D., and Teichmüller, R., 1982. Stach's Textbook of Coal Petrology (3rd ed.): Berlin (Gebrüder Borntraeger).

Stein, R., 1991. Accumulation of Organic Carbon in Marine Sediments: Results from the Deep Sea Drilling Project/Ocean Drilling Program $(D S D P / O D P)$. Lect. Notes Earth Sci., 34: Heidelberg (Springer-Verlag).

Stein, R., and Littke, R., 1990. Organic-carbon-rich sediments and paleoenvironment: results from Baffin Bay (ODP-Leg 105) and the upwelling area off Northwest Africa (ODP-Leg 108). In Huc, A.Y. (Ed.), Deposition of Organic Facies. AAPG Stud. in Geol., 30:41-56.

Stein, R., ten Haven, H.L., Littke, R., Rullkötter, J., and Welte, D.H., 1989. Accumulation of marine and terrigenous organic carbon at upwelling Site 658 and nonupwelling Sites 657 and 659: implications for the reconstruction of paleoenvironments in the eastern subtropical Atlantic through late
Cenozoic times. In Ruddiman, W., Sarnthein, M., et al., Proc. ODP, Sci. Results, 108: College Station, TX (Ocean Drilling Program), 361-385.

Summerhayes, C., 1986. Organic-rich Cretaceous sediments from the North Atlantic. In Brooks, J., and Fleet, A.J. (Eds.), Marine Petroleum Source Rocks. Geol. Soc. Spec. Publ. London, 301-316.

ten Haven, H.L., Rullkötter, J., and Stein, R., 1989. Preliminary analysis of extractable lipids in sediments from the Eastern North Atlantic (Leg 108): comparison of a coastal upwelling area (Site 658) with a nonupwelling area (Site 659). In Ruddiman, W., Sarnthein, M., et al., Proc. $O D P$, Sci. Results, 108: College Station, TX (Ocean Drilling Program), 351-360.

Tiedemann, R., Sarnthein, M., and Shackleton, N.J., 1994. Astronomic time scale for the Pliocene Atlantic d18O and dust flux records of Ocean Drilling Program Site 659. Paleoceanography, 9:619-638.

Tiedemann, R., Sarnthein, M., and Stein, R., 1989. Climatic changes in the western Sahara: aeolo-marine sediment record of the last 8 million years (Sites 657-661). In Ruddiman, W., Sarnthein, M., et al., Proc. ODP, Sci. Results, 108: College Station, TX (Ocean Drilling Program), 241-277.

Tissot, B.P., and Welte, D.H., 1984. Petroleum Formation and Occurrence (2nd ed.): Heidelberg (Springer-Verlag).

Turon, J.L., 1984. Direct land/sea correlations in the last interglacial complex. Nature, 309:673-676.

Tyson, R.V., 1995. Sedimentary Organic Matter: Organic Facies and Palynofacies: London (Chapman \& Hall).

Van Andel, T.H., Heath, G.R., and Moore, T.C., 1975. Cenozoic tectonics, sedimentation and paleoceanography of the central equatorial Pacific. Geol. Soc. Am. Mem., 143:187-194.

Van Bennekom, A.J., and Berger, G.W., 1984. Hydrography and silica budget of the Angola Basin. Neth. J. Sea Res., 17:149-200.

van Leeuwen, R.J.W., 1989. Sea-floor distribution and Late Quaternary faunal patterns of planktonic and benthic foraminifers in the Angola Basin. Utrecht Micropaleontol. Bull., 38:1-287.

Verardo, C.D.J., and McIntyre, A., 1994. Production and destruction: control of biogenous sedimentation in the tropical Atlantic 0-300,000 years B.P. Paleoceanography, 9:63-86.

Verardo, D.J., and Ruddiman, W.F., 1996. Late Pleistocene charcoal in tropical Atlantic deep-sea sediments: climatic and geochemical significance. Geology, 24:855-857.

Verstraete, J.-M., 1992. The seasonal upwellings in the Gulf of Guinea. Progr. Oceanogr., 29:1-60.

Voituriez, B., and Herbland, A., 1982. Comparaison des systèmes productifs de l'Atlantique tropical Est: dômes thermiques, upwelling côtier et upwelling équatorial. Rapp. P.-V., Reun. Cons. Int. Explor. Mer, 180:114 130.

Wagner, T., 1993. Organisches Material in pelagisches Sedimenten: Glaziale/ Interglaziale Variationen im Europäischen Nordmeer. Ber. Sonderforschungsber. $313,42: 1-138$

Wagner, T., and Henrich, R., 1994. Organo- and lithofacies of glacial-interglacial deposits of the Norwegian-Greenland Sea: responses to paleoceanographic and paleoclimatic changes. Mar. Geol., 120:335-364.

Wagner, T., and Hölemann, J.A., 1995. Deposition of organic matter in the Norwegian-Greenland Sea during the past 2.7 million years. Quat. Res., 44:255-266.

Westerhausen, L., Poynter, J., Eglinton, G., Erlenkeuser, H., and Sarnthein, M., 1993. Marine and terrigenous origin of organic matter in modern sediments of the equatorial East Atlantic: the $\delta^{13} \mathrm{C}$ and molecular record. Deep-Sea Res., 140:1087-1121.

Wiesner, M.G., Haake, B., and Wirth, H., 1990. Organic facies of surface sediments in the North Sea. Org. Geochem., 15:419-432.

Wu, G., and Berger, W.H., 1991. Pleistocene $\delta^{18} \mathrm{O}$ records from Ontong-Java Plateau: effects of winnowing and dissolution. Mar. Geol., 96:193-209.

Zafiriou, O.C., Gagosian, R.B., Peltzer, E.T., Alford, J.B., and Loder, T., 1985. Air-to-sea fluxes of lipids at Enewetak Atoll. J. Geophys. Res., 90:2409-2433.

Date of initial receipt: 10 September 1996

Date of acceptance: 11 June 1997

Ms 159SR-018 